\title{
Wheat Herbage Amendments Alter Emergence Dynamics, Seedling Growth of Lambsquarter and SoIl Properties ${ }^{1}$
}

\author{
Alterações de Forragem de Trigo Modificam a Dinâmica de Emergência, Crescimento das \\ Plântulas de Lambsquarter e Propriedades do Solo
}

\author{
ASLAM, F. ${ }^{2}$, KHALIQ, A. ${ }^{2}$, TANVEER, A. ${ }^{2}$, and ZAHIR, Z.A. ${ }^{2}$
}

\begin{abstract}
Crop allelopathy is a potential tool for weed management but allelopathic potential often varies among cultivars and developmental stages of crop. Bioassays were conducted to appraise the allelopathic potential of herbage (incorporated at $8 \mathrm{~g} \mathrm{~kg}^{-1}$ soil) of different hexaploid wheat (Triticum aestivum) cultivars (Millat-2011, AARI-2011, Lasani-2008 and Faisalabad-2008) collected at different crop growth stages [tillering (Z-30), anthesis (Z-60) and maturity (Z-90)] against lambsquarter (Chenopodium album). Mean emergence time taken by lambsquarter was prolonged over control by anthesis and maturity stage herbage of all wheat cultivars. Final emergence percentage was dropped by $3-17 \%$ in response to different growth stages of herbage collection. Maximum suppression in shoot (45 and $78 \%$ ) and root (60 and 90\%) length, and seedling dry biomass (65 and 96\%) of lambsquarter over control was recorded under the amendment of anthesis and maturity stages herbage of wheat cultivars. Total chlorophyll contents declined in response to herbage collected at anthesis and maturity stage of all wheat cultivars over control. Phenolic contents on the other hand were increased. Activities of enzymatic antioxidants also varied among all wheat cultivars, and declined by the incorporation of tillering, anthesis and maturity stage herbage. Wheat herbage induced lipid peroxidation in lambsquarter seedling and higher malondialdehyde content $\left(0.56\right.$ and $\left.0.77 \mathrm{nmol} \mathrm{g}^{-1} \mathrm{FW}\right)$ was observed by the incorporation of wheat cultivars herbage collected at anthesis and maturity stage, respectively. Anthesis and maturity stage herbage of wheat cultivars Millat-2011, AARI-2011 and Lasani-2008 was more phytotoxic than Faisalabad-2008. Moreover, tillering stage herbage of all wheat cultivars had less inhibitory potential against emergence, seedling growth and biochemical attributes of lambsquarter. Wheat herbage amendment increased the soil $\mathrm{pH}$, phenolic, organic carbon and nitrogen contents as compared to control.
\end{abstract}

Keywords: crop allelopathy, emergence dynamics, phenolics, soil incorporation, wheat growth stage

RESUMO - A alelopatia das colheitas é uma ferramenta potencial para o manejo de plantas daninhas, porém o potencial alelopático varia frequentemente entre cultivares e estágios de desenvolvimento da cultura. Foram realizados bioensaios para avaliar o potencial alelopático de forragem (incorporada em solo de $8 \mathrm{~g} \mathrm{~kg}^{-1}$ ) de diferentes cultivares de trigo hexaploide (Triticum aestivum) (Millat-2011, AARI-2011, Lasani-2008 e Faisalabad2008) coletados em diferentes estágios de crescimento das culturas [perfilhamento (Z-30), antese (Z-60) e maturidade (Z-90)] contra a planta lambsquarter (Chenopodium album). O tempo médio de emergência despendido pela lambsquarter foi prolongado pelo controle por antese e estágio de maturidade da forragem de todos os cultivares de trigo. A porcentagem de emergência final foi reduzida em 3-17\% em resposta a diferentes estágios de desenvolvimento da forragem coletada. A supressão máxima no comprimento da parte aérea (45 e 78\%) e das raízes (60 e 90\%) e a biomassa seca das plântulas (65 e 96\%) de lambsquarter, em relação ao controle, foram registradas no âmbito da alteração da antese e do estágio de maturidade da forragem de cultivares de trigo. O conteúdo total de

Recebido para publicação em 18.6.2015 e aprovado em 4.8.2015.

University of Agriculture, Faisalabad, Pakistan, <khaliquaf@gmail.com>. 
clorofila diminuiu em resposta à forragem coletada em antese e estágio de maturidade de todos os cultivares de trigo, em comparação ao controle. O conteúdo fenólico, por outro lado, foi aumentado. As atividades de antioxidantes enzimáticos também variaram entre todos os cultivares de trigo e diminuíram pela incorporação de perfilhamento, antese $e$ estágio de maturidade da forragem. A forragem de trigo induziu peroxidação lipídica em mudas de lambsquarter, e maior teor de malondialdeido (0,56 e 0,77 $\left.\mathrm{nmol} \mathrm{g}^{-1} \mathrm{FW}\right)$ foi observado pela incorporação de forragens de cultivares de trigo coletadas em antese e no estágio de maturidade, respectivamente. A antese e o estágio de maturidade de forragem dos cultivares de trigo Millat-2011, AARI-2011 e Lasani-2008 foram mais fitotóxicos do que os de Faisalabad-2008. Além disso, a forragem do estágio de perfilhamento de todos os cultivares de trigo teve menos potencial inibidor contra emergência, crescimento de plântulas e atributos bioquímicos de lambsquarter. A alteração da forragem de trigo aumentou os teores de $\mathrm{pH}$ do solo, de compostos fenólicos, de carbono orgânico e de nitrogênio, em relação ao controle.

Palavras-chave: alelopatia das culturas, dinâmica de emergência, compostos fenólicos, incorporação no solo, estágio de crescimento do trigo.

\section{INTRODUCTION}

Herbicides are commonly used to control weeds in wheat fields, securing quality and quantity of the final produce (Khaliq et al., 2011a). Nevertheless, continuous herbicide use has resulted in the evolution of resistant weed biotypes, and is leading to environment pollution as well (Khaliq et al., 2011a). Weed resistance to herbicides has emerged as a greatest ecological challenge to agriculture (Baucom, 2009), and more than 246 herbicideresistant weed biotypes (103 monocots and 143 dicots) have been reported (Heap, 2015). Moreover, in the backdrop of sustainable agriculture and negative implications of extensive use of synthetic herbicides, need is felt to switch from conventional weed management strategies to environmentally benign approaches. Accruing interest in ecological-based weed management has revealed the significance of allelopathy as a tool for sustainable weed management in agroecosystems (Albuquerque et al., 2011). Allelopathic interactions thus can be used to achieve selective weed control in field crops (Weston \& Duke, 2003). Wheat (Triticum aestivum) is known to possess allelopathic potential against weeds and crops (Khaliq et al., 2011b; Khaliq \& Matloob, 2012). Some wheat accessions have significantly inhibited (up to $75 \%$ ) the growth of several weeds that was equal to the suppression achieved by hand weeding (Rizvi et al., 2004). The allelopathic effects are species- and concentrationdependent (Wu et al., 2000; Belz \& Hurle, 2004), and are modified by the movement, persistence and fate of such chemicals upon entering the soil-plant interface (Inderjit, 2001). Crop allelopathy also varies in response to plant age so that different development stages have corresponded to varying levels of allelochemicals and their relative concentrations (An et al., 2003; Iannucci et al., 2012). Allelopathy can help suppress weeds at the vegetative growth stage through the exudation of allelochemicals into the growth medium, thus limiting the need for application of synthetic chemicals at early growth stages. At the post-harvest stage, the concentration of allelochemicals in plant's root and shoot tissues increases and affects the emergence and seedling growth of weeds via leaching and residue decomposition (Wu et al., 2000).

Lambsquarter (Chenopodium album), amongst other broad-leaved weeds of wheat, has been reported as a troublesome weed in term of its highest phytosociological frequency, herbage cover and density (Siddiqui $\&$ Bajwa, 2001). In many European countries, lambsquarter has evolved resistance to many herbicides like atrazine, metribuzin and linuron (Eleftherohorinos, 2000). Oad et al. (2007) have reported wheat grain yield losses 
of 40,35 and $36 \%$ owing to lambsquarter, canary grass (Phalaris minor) and wild oat (Avena fatua), respectively, when wheat was grown with these weeds in a $2: 1$ ratio. In a recent study, Siddiqui et al. (2010) have observed a wheat grain yield loss of $23 \%$ by lambsquarter infestation. Anjum \& Bajwa (2007) have reported the possibility of exploiting the sunflower allelopathic potential against this weed. Nevertheless, comprehensive studies regarding the allelopathic activity of wheat against emergence dynamics, seedling growth and biochemical attributes of lambsquarter are lacking, while information about the relative allelopathic effect of different growth stages of wheat against this weed is rarely investigated. The identification of wheat cultivars with a strong allelopathic potential can directly contribute to suppression of this weed by inclusion into crop rotation, or these can be used in breeding programs to incorporate this as a desirable trait into future genotypes, making them compete as well as suppress weeds more effectively. There is an evergrowing consensus that the genotypic variation responsible for allelopathy can be exploited as an integral component of an integrated weed management program. In a recent past, a number of high yielding wheat cultivars with contrasting morphophysiological attributes has been released to abridge the yield gap in Pakistan. While a lot of data regarding their yield potential and yield contributing traits are available, little is known about their allelopathic ability against weeds of economic significance. The present study was therefore designed to appraise the allelopathic potential of different wheat cultivars against lambsquarter emergence and seedling growth. Furthermore, induced biochemical changes in lambsquarter in response to negative effects of wheat allelopathy were also investigated. The paper also provides information on changes in some selected soil properties because of wheat herbage incorporation.

\section{MATERIALS AND METHODS}

\section{Herbage collection and analyses}

Whole plant herbage of four hexaploid wheat cultivars (Millat-2011, AARI-2011,
Lasani-2008 and Faisalabad-2008) was collected at three different growth stages (tillering (Z-30), anthesis (Z-60) and maturity (Z-90) according to Zadoks scale (Zadoks et al., 1974) from field plots grown at Agronomic Research Area, University of Agriculture Faisalabad, Pakistan $\left(31.25^{\circ} \mathrm{N}, 73.09^{\circ} \mathrm{E}\right.$, $184 \mathrm{~m}$ asl). The herbage was chopped with an electric fodder cutter into $2-3 \mathrm{~cm}$ pieces and dried under shade to constant moisture content. Herbage of all four wheat cultivars collected at different growth stages was analyzed for water-soluble phenolics as per Swain \& Hillis (1959) using Folin-Ciocalteu reagent (FCR), and expressed as gallic acid equivalent. Herbage was also analyzed for total carbon and nitrogen following BlackWalkley, and Kjeldahl's digestion methods, respectively (Ryan et al., 2001). Measurements were madeby repeating the whole procedures thrice, and average values are presented (Table 1).

\section{Bioassays study}

Lambsquarter seeds were collected from plants growing in fields where heavy infestation of this weed was found. Seeds were manually cleaned to ensure physical purity and the surface was sterilized with a water:bleach solution (10:1) for 15 minutes and then rinsed with distilled water four times. Plastic pots measuring $10 \times 26 \mathrm{~cm}$ (5 kg capacity) were filled with air-dried and well mixed field soil. Soil belongs to the Lyallpur soil series (Aridisolfine-silty, mixed, hyperthermic Ustalfic, Haplargid in USDA classification, and Haplic Yermosols in the FAO classification scheme (Cheema $\&$ Khaliq, 2000). The $\mathrm{pH}$ of saturated soil paste and electrical conductivity of the saturation extract were 7.4 and $0.69 \mathrm{dS} \mathrm{m}^{-1}$, respectively. Since it was difficult to sterilize soil in bulk, hence soil was subjected to suicidal germination twice to ensure germination of viable weed seeds (Khaliq \& Matloob, 2012). The herbage collected at different growth stages of wheat cultivars was incorporated at the rate of $8 \mathrm{~g} \mathrm{~kg}^{-1}$ soil (16 tons ha-1). The control treatment consisted in soil without herbage amendment. After seven days of herbage incorporation, twenty seeds of lambsquarter were sown per pot. These pots were placed in a wire house under natural conditions with a 


\begin{tabular}{|c|c|c|c|c|c|}
\hline \multirow{3}{*}{ 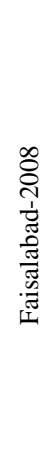 } & $\begin{array}{l}\text { 害 } \\
\text { 劳 }\end{array}$ & 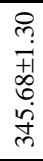 & 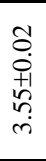 & $\begin{array}{l}\hat{m} \\
\hat{\sigma}\end{array}$ & 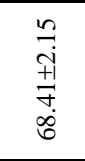 \\
\hline & 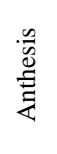 & 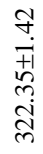 & $\begin{array}{l}\hat{0} \\
\text { o. } \\
\text { +1 } \\
\dot{0} \\
\dot{+}\end{array}$ & $\begin{array}{c}\infty \\
\stackrel{m}{\infty} \\
\infty\end{array}$ & 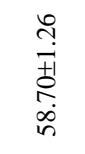 \\
\hline & 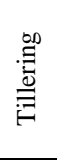 & 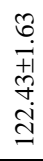 & 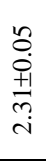 & $\begin{array}{l}8 \\
\text { ભે }\end{array}$ & 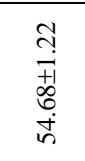 \\
\hline \multirow{3}{*}{ 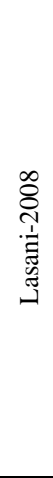 } & $\begin{array}{l}\text { 意 } \\
\text { 营 }\end{array}$ & 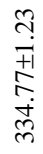 & 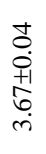 & $\begin{array}{l}\text { Ñ } \\
\sigma\end{array}$ & 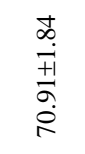 \\
\hline & 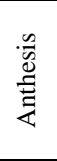 & 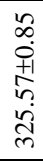 & 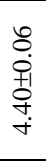 & 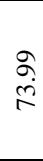 & $\begin{array}{l}\overrightarrow{i n} \\
\stackrel{+}{+1} \\
\stackrel{+}{+} \\
\stackrel{0}{0}\end{array}$ \\
\hline & 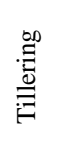 & 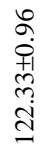 & 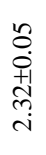 & 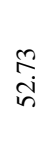 & 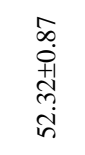 \\
\hline \multirow{3}{*}{ 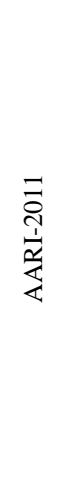 } & 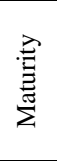 & 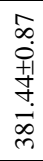 & $\begin{array}{l}\text { Nొ } \\
0 \\
0 \\
\infty \\
\infty \\
\infty\end{array}$ & $\begin{array}{l}\infty \\
\infty \\
\infty \\
\infty\end{array}$ & 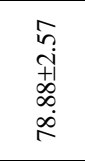 \\
\hline & 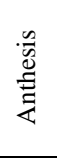 & 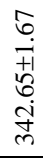 & 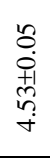 & 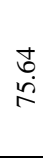 & $\begin{array}{l}0 \\
0 \\
i \\
i \\
\infty \\
\infty \\
-1 \\
0 \\
0\end{array}$ \\
\hline & 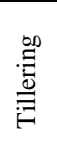 & 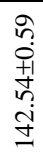 & $\begin{array}{l}\text { 오 } \\
\stackrel{+}{+} \\
+1 \\
\stackrel{+}{+} \\
\stackrel{\sim}{v}\end{array}$ & $\underset{\hat{\imath}}{\mathrm{i}}$ & 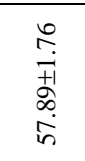 \\
\hline \multirow{3}{*}{ 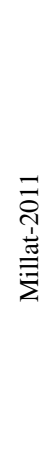 } & $\begin{array}{l}\text { 害 } \\
\text { 党 }\end{array}$ & 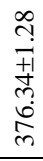 & $\begin{array}{l}\dot{y} \\
\dot{0} \\
\dot{+1} \\
\dot{+1} \\
\dot{\omega} \\
\dot{m}\end{array}$ & 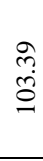 & 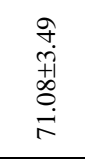 \\
\hline & 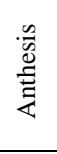 & 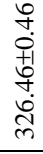 & $\begin{array}{l}\stackrel{0}{0} \\
0 \\
\stackrel{0}{11} \\
\stackrel{0}{+} \\
\stackrel{+}{+}\end{array}$ & 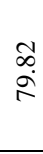 & $\begin{array}{l}\vec{\sigma} \\
\dot{\oplus} \\
+1 \\
\infty \\
\infty \\
\dot{\sigma}\end{array}$ \\
\hline & 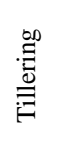 & 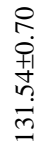 & 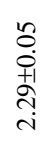 & 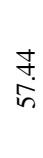 & 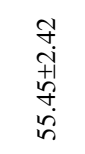 \\
\hline & & 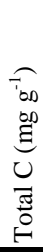 & 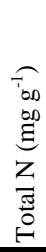 & ن̈ & 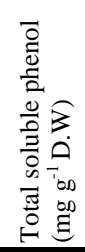 \\
\hline
\end{tabular}

$10 / 14 \mathrm{~h}$ light/dark photoperiod at a temperature $15 \pm 2{ }^{\circ} \mathrm{C}$ and relative humidity $70 \pm 2$. The pots were irrigated as and when required to avoid water stress.

\section{MATERIAL AND METHODS}

\section{Emergence dynamics and seedling growth of lambsquarter}

Emergence counts were recorded daily as suggested by AOSA (1990) until emergence became constant. A criterion for emergence was set to over $2 \mathrm{~mm}$ hypocotyl length as visible to naked eye. Time taken to $50 \%$ emergence of seedlings $\left(\mathrm{E}_{50}\right)$ was calculated according to the modified formulae by Farooq et al. (2005):

$$
E_{50}=t_{i}+\frac{\left(\frac{N}{2}-n_{i}\right)\left(t_{j}-t_{i}\right)}{n_{j}-n_{i}}
$$

where "N" refers to the final number of emerged seeds, and " $n_{i}$ " and " $n_{j}$ " are the cumulative number of seeds that emerged by adjacent counts at times " $t_{i}$ " and " $t_{j}$ " where $\mathrm{n}_{\mathrm{i}}<\mathrm{N} /{ }_{2}<\mathrm{n}_{\mathrm{j}}$. Mean emergence time (MET) was calculated as per Ellis \& Robert (1981):

$$
\mathrm{MET}=\frac{\sum \mathrm{Dn}}{\sum \mathrm{n}}
$$

where " $n$ " denotes the number of seeds, which were emerged on day " $D$ ", and " $D$ " is the number of days counted from the beginning of emergence.

Emergence Index (EI) was calculated as described by AOSA (1983):

EI $=\frac{\text { No. of emerged seeds }}{\text { Days of first count }}+---+\frac{\text { No. of emerged seeds }}{\text { Days of final count }}$

Final emergence percentage (FEP) was calculated as the ratio of emerged seeds to the total number of seeds sown and expressed as $\%$. Root and shoot lengths were measured 6 weeks after sowing with a measuring tape. All roots and shoots from each pot were cut separately and oven dried at $70{ }^{\circ} \mathrm{C}$ for $48 \mathrm{~h}$ to get dry biomass of root and shoot; total seedling biomass was calculated as the sum of biomass of the root and shoot. 


\section{Biochemical analyses of lambsquarter seedlings}

Total soluble phenolics in leaves of lambsquarter seedling were determined as described by Randhir \& Shetty (2005), and are expressed as gallic acid equivalents. Photosynthetic pigments (Chl. a and Chl. b) were extracted in $80 \%$ ice cold acetone and read out at 663 and $645 \mathrm{~nm}$ wavelength in a UV-spectrophotometer (UV-4000, ORI, Germany). These are expressed as $\mathrm{mg} \mathrm{g}^{-1}$ fresh leaf weight (Arnon, 1994). Soluble proteins were measured using crystalline bovine albumin as a reference (Bradford, 1976). Activity of superoxide dismutase (SOD) was measured as described by Giannopotitis \& Ries (1977) at $560 \mathrm{~nm}$. One unit of SOD activity was defined as the amount of enzyme inhibiting the photochemical reduction of NBT by $50 \%$ per minute. The catalase (CAT) activity based on the consumption of $\mathrm{H}_{2} \mathrm{O}_{2}$ was determined using the method of Dhindsa et al. (1981). The consumption of $\mathrm{H}_{2} \mathrm{O}_{2}$ was observed at $240 \mathrm{~nm}$ and one unit of CAT was defined as the amount of enzyme required to oxidize $1 \mu \mathrm{M} \mathrm{H}_{2} \mathrm{O}_{2} \mathrm{~min}^{-1}$. The peroxidase (POX) activity was recorded as described by Egley et al. (1983). Increase in absorbance due to guaiacol oxidation was measured at $470 \mathrm{~nm}$. One unit of enzymatic activity was defined as the amount of enzyme required to oxidize $1 \mu \mathrm{M}$ guaiacol $\mathrm{min}^{-1}$. Lipid peroxidation in leaves of wheat seedling was determined as malondialdehyde (MDA) content following the thiobarbituric acid method (Bailly et al., 1996). The absorbance of supernatant was read at $532 \mathrm{~nm}$ and corrected for nonspecific absorbance at $600 \mathrm{~nm}$. The MDA content was calculated using an extinction coefficient of $155 \mathrm{mM}^{-1} \mathrm{~cm}$.

\section{Analyses of wheat herbage amended soil}

The $\mathrm{pH}$ of the wheat cultivars herbage amended soil was measured by using a digital pH meter (HI-9811, Hannah, USA). Soil phenolics were determined with a UVspectrophotometer (UV-4000, ORI, Germany) as per Box (1983) and are expressed as vanillic acid equivalents. Measurements were made by repeating the whole procedures thrice, and average values are given in Tables 2 and 3.

\section{Experimental design and statistical analyses}

The experiment was conducted using a completely randomized design with four replications and repeated once in the same season. Since the results of two runs of the whole experiment were similar, data were pooled for combined analyses. Following the Fisher's analysis of variance technique (Steel et al., 1997), mean values were separated using the least significant difference (LSD) test at $p<0.05$ using a computer statistical program (Statistix 8.1, Analytical software, Statistix; Tallahassee, FL, USA, 1985-2003). To ascertain the relationship among different variables, correlation analyses were also done.

\section{RESULTS AND DISCUSSION}

\section{Properties of wheat herbage}

Chemical properties of herbage of all wheat cultivars differed with growth stages. Maximum carbon (342 and $381 \mathrm{mg} \mathrm{g}^{-1}$ ) and nitrogen contents ( 4.53 and $3.88 \mathrm{mg} \mathrm{g}^{-1}$ ) were recorded for anthesis and maturity stage herbage of wheat cultivar AARI-2011, respectively, as compared to the tillering stage (Table 1). Carbon nitrogen ratio $(\mathrm{C}: \mathrm{N})$ was narrow for the tillering stage herbage but wider for anthesis and maturity stage herbage. Upper limit of C:N (103) was observed for herbage of wheat cultivar Millat-2011 collected at the maturity stage. Total soluble phenolic contents in herbage of different wheat cultivars ranged from $52-78 \mathrm{mg} \mathrm{g}^{-1} \mathrm{DW}$ (Table 1).

\section{Properties of herbage incorporated soil}

Incorporation of wheat herbage of different wheat cultivars collected at tillering, anthesis and maturity stage changed the selected soil properties as compared to the control (Table 2). Total soluble phenolic contents in soil were increased after herbage incorporation. Soil phenolic contents, however, declined at harvesting time. Upper limit of soil phenolic contents at the time of sowing ( $24 \mathrm{mg} \mathrm{g}^{-1}$ soil) and harvesting (18 $\mathrm{mg} \mathrm{g}^{-1}$ soil) was recorded by the incorporation of wheat herbage of cultivar 
Table 2 - Total soluble phenolic contents and pH of soil incorporated with wheat herbage of different growth stages

\begin{tabular}{|c|c|c|c|c|c|c|c|c|}
\hline & \multicolumn{2}{|c|}{ Millat-2011 } & \multicolumn{2}{|c|}{ AARI-2011 } & \multicolumn{2}{|c|}{ Lasani-2008 } & \multicolumn{2}{|c|}{ Faisalabad-2008 } \\
\hline & *At sowing & $\begin{array}{c}* * \text { At } \\
\text { harvesting }\end{array}$ & At sowing & $\begin{array}{c}\text { At } \\
\text { harvesting }\end{array}$ & At sowing & $\begin{array}{c}\text { At } \\
\text { harvesting }\end{array}$ & At sowing & $\begin{array}{c}\text { At } \\
\text { harvesting }\end{array}$ \\
\hline & \multicolumn{8}{|c|}{ Total soluble phenolics (mg g ${ }^{-1}$ soil) } \\
\hline Control & $11.24 \pm 0.85$ & $7.99 \pm 1.29$ & $11.24 \pm 0.85$ & $7.99 \pm 1.29$ & $11.24 \pm 0.85$ & $7.99 \pm 1.29$ & $11.24 \pm 0.85$ & $7.99 \pm 1.29$ \\
\hline Tillering & $14.01 \pm 0.84$ & $10.97 \pm 1.16$ & $15.91 \pm 0.95$ & $14.91 \pm 0.89$ & $14.79 \pm 0.89$ & $10.79 \pm 0.85$ & $13.68 \pm 0.82$ & $9.71 \pm 1.04$ \\
\hline Anthesis & $17.02 \pm 1.02$ & $12.01 \pm 0.84$ & $21.70 \pm 1.30$ & $15.76 \pm 1.30$ & $15.24 \pm 0.91$ & $13.76 \pm 1.22$ & $14.57 \pm 0.87$ & $13.35 \pm 1.11$ \\
\hline \multirow[t]{2}{*}{ Maturity } & $19.84 \pm 0.75$ & $16.74 \pm 0.85$ & $24.20 \pm 1.49$ & $18.40 \pm 1.53$ & $18.02 \pm 1.08$ & $15.24 \pm 0.91$ & $16.24 \pm 0.97$ & $14.90 \pm 1.66$ \\
\hline & \multicolumn{8}{|c|}{$\mathrm{pH}$} \\
\hline Control & $7.4 \pm 0.04$ & $7.2 \pm 0.06$ & $7.4 \pm 0.04$ & $7.2 \pm 0.06$ & $7.4 \pm 0.04$ & $7.2 \pm 0.06$ & $7.4 \pm 0.04$ & $7.2 \pm 0.06$ \\
\hline Tillering & $7.4 \pm 0.05$ & $7.6 \pm 0.06$ & $7.5 \pm 0.01$ & $7.6 \pm 0.05$ & $7.5 \pm 0.05$ & $7.7 \pm 0.06$ & $7.4 \pm 0.01$ & $7.6 \pm 0.03$ \\
\hline Anthesis & $7.5 \pm 0.05$ & $7.7 \pm 0.07$ & $7.6 \pm 0.07$ & $7.8 \pm 0.05$ & $7.6 \pm 0.07$ & $7.8 \pm 0.01$ & $7.5 \pm 0.06$ & $7.7 \pm 0.03$ \\
\hline \multirow[t]{2}{*}{ Maturity } & $7.6 \pm 0.08$ & $7.7 \pm 0.02$ & $7.7 \pm 0.03$ & $7.8 \pm 0.01$ & $7.6 \pm 0.02$ & $7.8 \pm 0.05$ & $7.6 \pm 0.04$ & $7.8 \pm 0.00$ \\
\hline & \multicolumn{8}{|c|}{ Organic carbon (\%) } \\
\hline Control & $0.38 \pm 0.15$ & $0.14 \pm 0.06$ & $0.38 \pm 0.15$ & $0.14 \pm 0.06$ & $0.38 \pm 0.15$ & $0.14 \pm 0.06$ & $0.38 \pm 0.15$ & $0.14 \pm 0.06$ \\
\hline Tillering & $0.55 \pm 0.09$ & $1.40 \pm 0.08$ & $0.59 \pm 0.12$ & $1.55 \pm 0.07$ & $0.42 \pm 0.06$ & $1.44 \pm 0.08$ & $0.37 \pm 0.09$ & $1.34 \pm 0.10$ \\
\hline Anthesis & $0.49 \pm 0.08$ & $1.52 \pm 0.13$ & $0.78 \pm 0.11$ & $1.55 \pm 0.11$ & $0.65 \pm 0.15$ & $1.48 \pm 0.07$ & $0.60 \pm 0.11$ & $1.39 \pm 0.07$ \\
\hline \multirow[t]{2}{*}{ Maturity } & $0.66 \pm 0.12$ & $1.76 \pm 0.08$ & $0.72 \pm 0.10$ & $1.80 \pm 0.11$ & $0.95 \pm 0.07$ & $1.71 \pm 0.11$ & $0.76 \pm 0.13$ & $1.55 \pm 0.09$ \\
\hline & \multicolumn{8}{|c|}{ Available nitrogen $\left(\mathrm{kg} \mathrm{ha}^{-1}\right)$} \\
\hline Control & $89.23 \pm 1.78$ & $51.84 \pm 1.65$ & $89.23 \pm 1.78$ & $51.84 \pm 1.65$ & $89.23 \pm 1.78$ & $51.84 \pm 1.65$ & $89.23 \pm 1.78$ & $51.84 \pm 1.65$ \\
\hline Tillering & $101.66 \pm 1.58$ & $129.95 \pm 1.29$ & $122.08 \pm 1.41$ & $144.26 \pm 2.01$ & $112.06 \pm 1.27$ & $134.36 \pm 1.97$ & $104.79 \pm 1.89$ & $130.09 \pm 1.09$ \\
\hline Anthesis & $127.39 \pm 0.91$ & $152.05 \pm 1.16$ & $139.33 \pm 1.45$ & $161.96 \pm 1.63$ & $125.11 \pm 2.30$ & $152.63 \pm 1.72$ & $117.61 \pm 1.93$ & $150.36 \pm 2.12$ \\
\hline Maturity & $141.89 \pm 1.49$ & $180.85 \pm 2.10$ & $144.48 \pm 1.86$ & $183.72 \pm 2.38$ & $136.60 \pm 1.48$ & $176.08 \pm 0.87$ & $131.89 \pm 1.03$ & $169.32 \pm 1.92$ \\
\hline
\end{tabular}

\pm S.E, * Soil samples were collected after 7 days of wheat herbage incorporation at the time of sowing, **Soil samples were collected at the time of harvesting.

AARI-2011 collected at the maturity stage as compared to the control. Higher organic carbon (0.78 and $1.55 \%$, and 0.72 and $1.80 \%)$ and nitrogen contents (139 and $161 \mathrm{~kg} \mathrm{ha}^{-1}$, and 144 and $183 \mathrm{~kg} \mathrm{ha}^{-1}$ ) in soil were noticed in response to herbage of anthesis and maturity stage of wheat cultivar AARI-2011 at the time of sowing and harvesting, respectively, as compared to the tillering stage of the same wheat cultivar and control (Table 2). The $\mathrm{pH}$ value of the herbage amended soil was higher at the time of sowing (7.5-7.7) and harvesting (7.6-7.8) as compared to the initial $\mathrm{pH}$ values of the control soil (7.4 and 7.2 at these times).

\section{Emergence attributes}

Soil incorporated herbage collected at different growth stages (tillering, anthesis and maturity) of four wheat cultivars (Millat-2011, AARI-2011, Lasani-2008 and Faisalabad-2008) significantly $(p \leq 0.05)$ affected the emergence attributes of lambsquarter (Table 3). Interactive effect between wheat cultivars and growth stages of herbage collection was nonsignificant $(p \leq 0.05)$ for most of the emergence attributes except $\mathrm{E}_{50}$ and MET, whereas the influence of wheat cultivars was significant $(p \leq 0.05)$ for EI only (Table 1$)$. Nevertheless, growth stages at which herbage was collected had a more pronounced effect on the emergence dynamics of lambsquarter. Time to start emergence (TSE) was delayed beyond 2 days over control when herbage of anthesis and maturity stage was soil incorporated. The maximum drop in EI of lambsquarter was observed in response to soil incorporation of maturity stage wheat herbage as compared to the control (Table 3). The drop in EI due to the incorporation of wheat herbage collected at anthesis stage was statistically similar to control. The $\mathrm{E}_{50}$ of lambsquarter 
Table 3 - Influence of soil incorporation of wheat herbage of different growth stages on emergence dynamics of lambsquarter

\begin{tabular}{|c|c|c|c|c|c|}
\hline \multicolumn{6}{|c|}{ Cultivar } \\
\hline Growth stages & Millat-2011 & AARI-2011 & Lasani-2008 & Faisalabad-2008 & Mean \\
\hline \multicolumn{6}{|c|}{ TSE (days) } \\
\hline Control & $6.25^{\mathrm{n} . \mathrm{s}}$ & 6.25 & 6.25 & 6.25 & $6.25 \mathrm{C}$ \\
\hline Tillering & 7.25 & 6.75 & 7.00 & 7.00 & $7.00 \mathrm{~B}$ \\
\hline Anthesis & 8.00 & 7.50 & 8.00 & 7.50 & $7.75 \mathrm{~A}$ \\
\hline Maturity & 7.50 & 8.00 & 7.50 & 8.00 & $7.75 \mathrm{~A}$ \\
\hline Mean & 7.25 & 7.13 & 7.19 & 7.19 & \\
\hline \multicolumn{3}{|c|}{ LSD $p \leq 0.05$} & \multicolumn{3}{|c|}{$\mathrm{C}=$ n.s, G.S $=0.441, \mathrm{C} \times \mathrm{G} . \mathrm{S}=$ n.s } \\
\hline \multicolumn{6}{|c|}{$\overline{E I}$} \\
\hline Control & $7.44^{\text {n.s }}$ & 7.44 & 7.44 & 7.44 & $7.44 \mathrm{~B}$ \\
\hline Tillering & 7.32 & 8.87 & 8.33 & 8.96 & $8.37 \mathrm{~A}$ \\
\hline Anthesis & 7.27 & 7.55 & 7.92 & 8.03 & $7.69 \mathrm{~B}$ \\
\hline Maturity & 6.92 & 6.47 & 7.10 & 7.11 & $6.90 \mathrm{C}$ \\
\hline Mean & $7.24 \mathrm{~B}$ & $7.58 \mathrm{AB}$ & $7.70 \mathrm{AB}$ & $7.89 \mathrm{~A}$ & \\
\hline \multicolumn{3}{|c|}{ LSD $p \leq 0.05$} & \multicolumn{3}{|c|}{$\mathrm{C}=0.462, \mathrm{G} . \mathrm{S}=0.462, \mathrm{C} \times \mathrm{G} . \mathrm{S}=\mathrm{n} . \mathrm{s}$} \\
\hline \multicolumn{6}{|c|}{ FEP } \\
\hline Control & $95.00^{\text {n.s }}$ & 95.00 & 95.00 & 95.00 & $95.00 \mathrm{~A}$ \\
\hline Tillering & 95.00 & 93.75 & 93.75 & 97.50 & $95.00 \mathrm{~A}$ \\
\hline Anthesis & 87.50 & 90.00 & 95.00 & 93.75 & $91.56 \mathrm{~B}$ \\
\hline Maturity & 78.75 & 76.25 & 80.00 & 80.00 & $78.75 \mathrm{C}$ \\
\hline Mean & 89.06 & 88.75 & 90.94 & 91.56 & \\
\hline \multicolumn{3}{|c|}{ LSD $p \triangleleft 0.05$} & \multicolumn{3}{|c|}{$\mathrm{C}=\mathrm{n} . \mathrm{s}, \mathrm{G} . \mathrm{S}=3.315, \mathrm{C} \times \mathrm{G} . \mathrm{S}=\mathrm{n} . \mathrm{s}$} \\
\hline
\end{tabular}

$\mathrm{C}=$ wheat cultivars, $\mathrm{G} . \mathrm{S}=$ growth stages, $\mathrm{C} \times \mathrm{G} . \mathrm{S}=$ wheat cultivars $\times$ growth stages, n.s $=$ nonsignificant. Each number is average of four replicates. Main effect means not sharing a letter in common differ significantly at 5\% probability level by LSD test.

remained statistically similar to control under incorporation of the tillering stage herbage of wheat cultivars Millat-2011, Lasani-2008 and Faisalabad-2008 (Figure 1A). Minimum $\mathrm{E}_{50}$ of lambsquarter was recorded under the incorporation of the tillering stage herbage of wheat cultivar AARI-2011 that was at par with $\mathrm{E}_{50}$ recorded under incorporation of herbage of Millat-2011 for the same growth stage. The $\mathrm{E}_{50}$ of lambsquarter remained statistically similar for all wheat cultivars herbage incorporation collected at anthesis and maturity stage, while maximum delay in $\mathrm{E}_{50}$ (14 and $\left.12 \%\right)$ was observed for wheat cultivars AARI-2011 and Lasani-2008 herbage of same growth stages. The MET of lambsquarter remained similar to control under incorporation of herbage of wheat cultivar Millat-2011 and AARI-2011 collected at the tillering stage. Significant $(p \leq 0.05)$ interaction of wheat cultivar $\mathrm{x}$ stages of herbage collection for MET suggested that mean emergence time did not vary among wheat cultivars for herbage collected at the maturity stage, however; this was also true for the pots incorporated with anthesis stage herbage of AARI-2011 and Lasani-2008 (Figure 1B). Nevertheless, differences were pronounced for herbage collected at tillering and anthesis stage and cultivar specific effects were evident. Soil incorporation of wheat herbage collected at anthesis and maturity stage significantly $(p \leq 0.05)$ inhibited the FEP of lambsquarter by 3 and $17 \%$ over control (Table 3). Overall, herbage of the tillering stage had a stimulatory effect on emergence attributes of lambsquarter as compared to control (Table 3).

\section{Seedling growth}

Regarding seedling growth of lambsquarter, interaction of wheat cultivars with stages of 


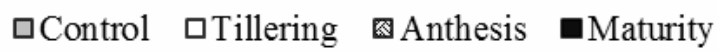
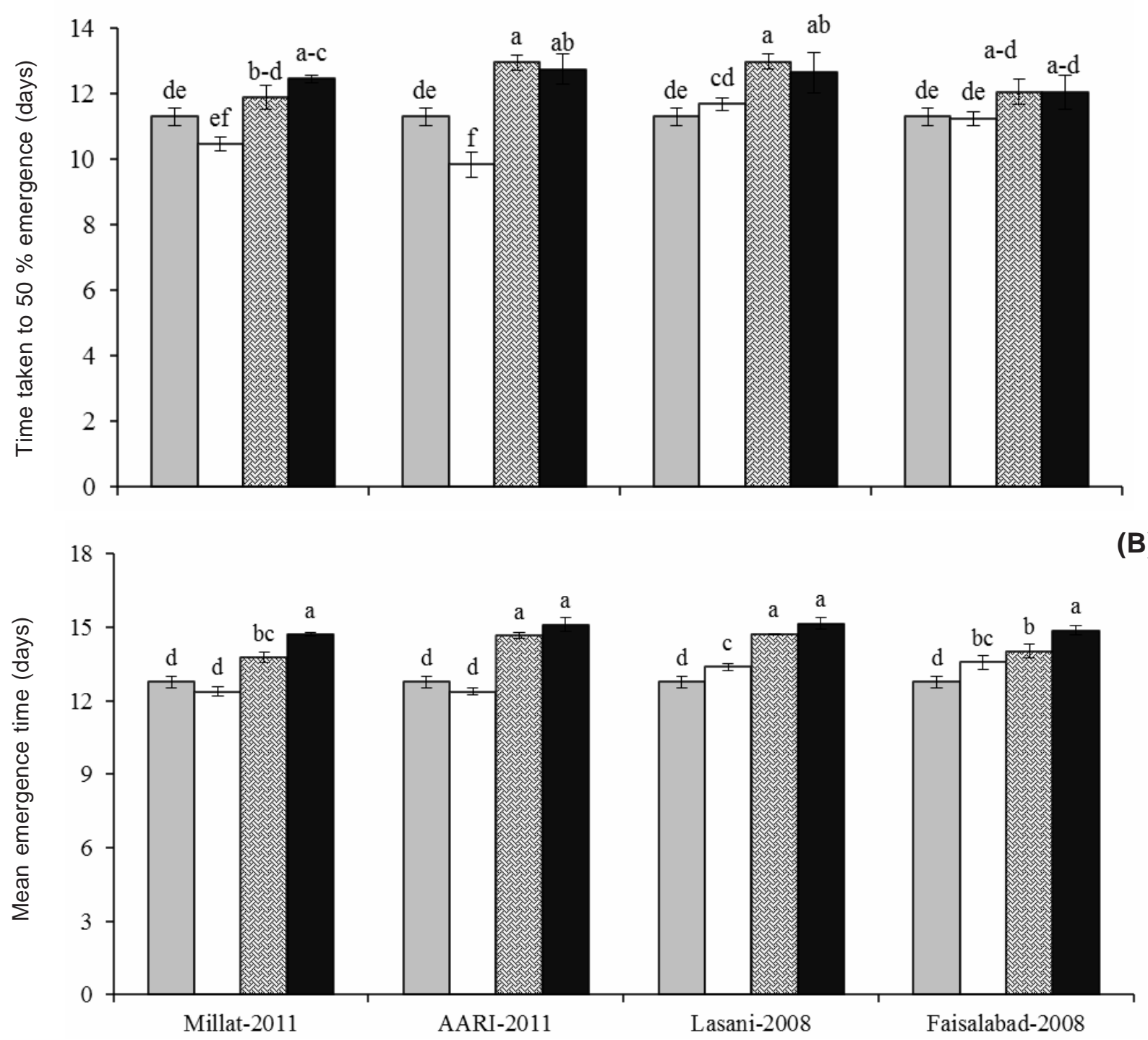

Figure 1 - Influence of soil incorporation of wheat herbage of different growth stages on (A) $\mathrm{E}_{50}$ and (B) MET of lambsquarter. Vertical bars above the means denote the standard error of four replicates. Interaction means not sharing a letter in common differ significantly at $5 \%$ probability test by LSD test. Critical value for comparison is (A) 0.953 , (B) 0.587 .

herbage collection was nonsignificant ( $p \leq 0.05)$ for most of the studied traits except root length. Nevertheless, growth stages at which herbage was collected had more a pronounced effect on seedling growth of lambsquarter. Shoot length of lambsquarter was decreased by 11,45 and $78 \%$ over control, when herbage collected at tillering, anthesis and maturity stage of wheat was soil incorporated (Table 4). Soil incorporation of herbage of all wheat cultivars at different growth stages significantly $(p \leq 0.05)$ reduced the root length of lambsquarter. The tillering stage herbage of cultivar Lasani-2008 significantly ( $p \leq 0.05)$ reduced root length and such reduction was statistically at par with that realized for herbage of AARI-2011 and Faisalabd-2008 at the same growth stage (Figure 2). For herbage collected at anthesis stage, wheat cultivar AARI-2011 was statistically at par with Lasani-2008, as was Millat-2011 at par with Faisalabad-2008 regarding root length of lambsquarter. Root length, however, did not vary among wheat cultivars when compared 
Table 4 - Influence of soil incorporation of wheat herbage of different growth stages on seedling growth of lambsquarter

\begin{tabular}{|c|c|c|c|c|c|}
\hline \multicolumn{6}{|c|}{ Cultivar } \\
\hline Growth stages & Millat-2011 & AARI-2011 & Lasani-2008 & Faisalabad-2008 & Mean \\
\hline \multicolumn{6}{|c|}{ Shoot length (cm) } \\
\hline Control & $23.54^{\mathrm{n} . \mathrm{s}}$ & 23.54 & 23.54 & 23.54 & $23.54 \mathrm{~A}$ \\
\hline Tillering & 22.47 & 21.06 & 19.25 & 20.54 & $20.83 \mathrm{~B}$ \\
\hline Anthesis & 14.50 & 11.20 & 12.15 & 13.47 & $12.83 \mathrm{C}$ \\
\hline Maturity & 5.67 & 4.74 & 5.03 & 4.70 & $5.03 \mathrm{D}$ \\
\hline Mean & 16.54 & 15.14 & 14.99 & 15.56 & \\
\hline \multicolumn{3}{|c|}{$\mathrm{LSD} p \triangleleft 0.05$} & \multicolumn{3}{|c|}{$\mathrm{C}=\mathrm{n} . \mathrm{s}, \mathrm{G} . \mathrm{S}=1.725, \mathrm{C} \times \mathrm{G} . \mathrm{S}=\mathrm{n} . \mathrm{s}$} \\
\hline \multicolumn{6}{|c|}{ Seedling dry biomass (mg) } \\
\hline Control & $461.42^{\text {n.s }}$ & 461.42 & 461.42 & 461.42 & $461.42 \mathrm{~A}$ \\
\hline Tillering & 434.20 & 483.60 & 466.91 & 415.12 & $449.96 \mathrm{~A}$ \\
\hline Anthesis & 185.63 & 91.99 & 118.64 & 164.72 & $140.24 \mathrm{~B}$ \\
\hline Maturity & 16.10 & 16.76 & 29.81 & 12.95 & $18.91 \mathrm{C}$ \\
\hline Mean & 274.34 & 263.44 & 269.20 & 263.55 & \\
\hline \multicolumn{3}{|c|}{ LSD $p \unlhd 0.05$} & \multicolumn{3}{|c|}{$\mathrm{C}=$ n.s, G.S $=33.688, \mathrm{C} \times \mathrm{G} . \mathrm{S}=\mathrm{n} . \mathrm{s}$} \\
\hline
\end{tabular}

$\mathrm{C}=$ wheat cultivars, $\mathrm{G} . \mathrm{S}=$ growth stages, $\mathrm{C} \times \mathrm{G} . \mathrm{S}=$ wheat cultivars $\times$ growth stages, $\mathrm{n} . \mathrm{s}=$ nonsignificant. Each number is average of four replicates, Main effect means not sharing a letter in common differ significantly at $5 \%$ probability level by LSD test.

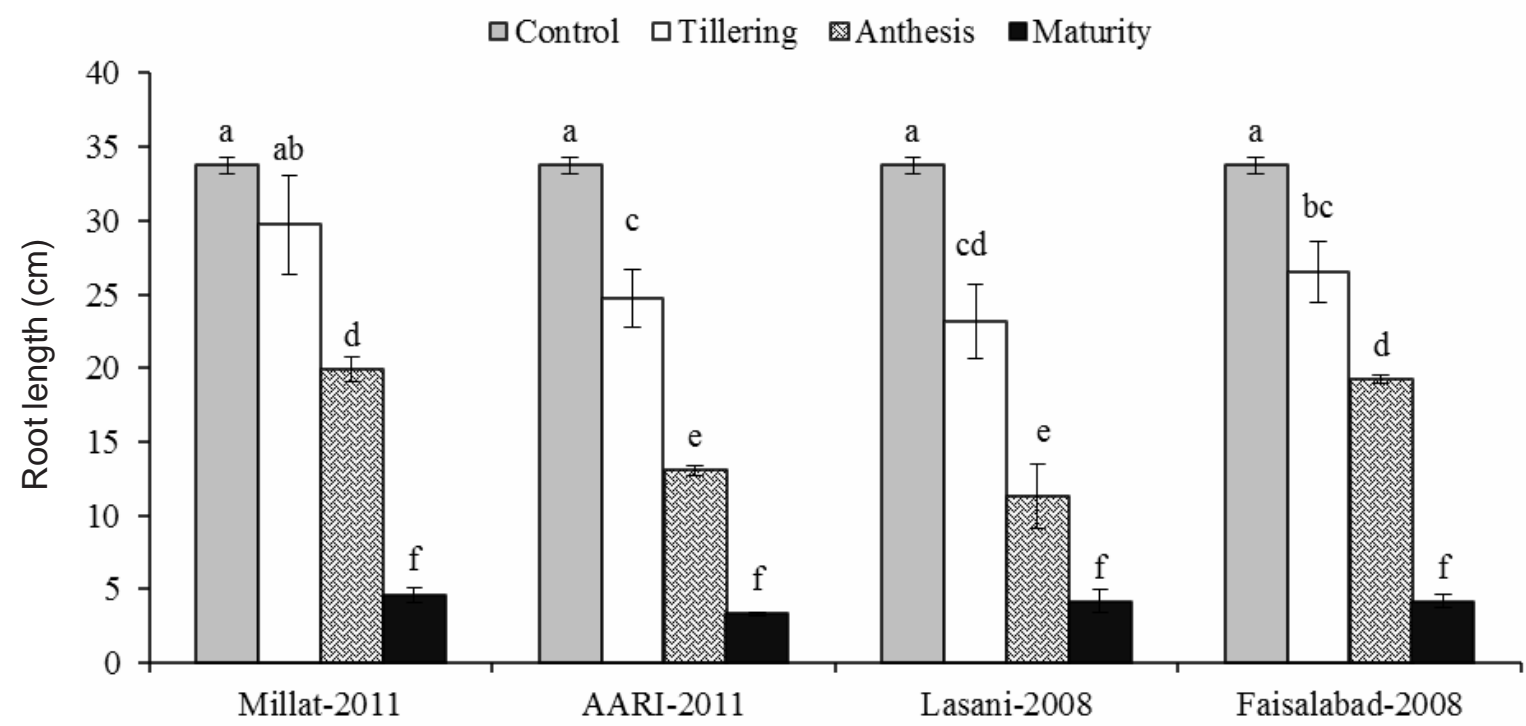

Figure 2 - Influence of soil incorporation of wheat herbage of different growth stages on root length of lambsquarter. Vertical bars above the means denote the standard error of four replicates. Interaction means not sharing a letter in common differ significantly at $5 \%$ probability test by LSD test. Critical value for comparison is 4.122 .

for maturity stage herbage. Seedling dry biomass of lambsquarter was significantly reduced by 65 and $96 \%$ by the incorporation of herbage collected at anthesis and maturity stage of wheat cultivars as compared to control (Table 4). Nevertheless, seedling dry biomass remained unaffected under the influence of tillering stage herbage incorporation as compared to control.

\section{Chlorophyll and soluble phenolic contents}

Interactive effect of wheat cultivars with stages of herbage collection was significant for 
Chlorophyll 'a', 'b' and total chlorophyll contents of lambsquarter seedling. Chlorophyll ' $a$ ' contents of lambsquarter declined over control under the amendment of herbage of wheat cultivars Millat-2011, Lasani-2008 and Faisalabad-2008 collected at tillering stage except by AARI-2011. Significantly $(p \leq 0.05)$ reduced chlorophyll 'a' contents were noticed for lambsquarter seedlings growing in pots amended with herbage of Millat-2011 collected at the anthesis stage (Figure 3A). Millat-2011 was at par with Lasani-2008 and Faisalabad2008 regarding chlorophyll 'a', as were Lasani-2008 and Faisalabad-2008 with AARI-2011 for the herbage of the same growth stage. Nevertheless, incorporation of herbage of maturity stage resulted in a statistically similar reduction of chlorophyll 'a' contents of lambsquarter, irrespective of wheat cultivars. Incorporation of herbage of wheat cultivars viz. Millat-2011, Lasani-2008 and Faisalabad-2008 collected at tillering stage significantly reduced chlorophyll 'b' contents of lambsquarter by 21,23 and $27 \%$ over control (Figure 3B). Chlorophyll 'b' contents remained statistically similar to control under incorporation of herbage of wheat cultivar AARI-2011 collected at the same growth stage. Chlorophyll 'b' contents did not vary among wheat cultivars for herbage collected at the anthesis stage (Figure 3B). Maximum reduction in chlorophyll ' $b$ ' contents of lambsquarter was recorded where herbage of wheat cultivar AARI-2011 collected at maturity stage was soil incorporated. For total chlorophyll, a similar trend was noticed as for chlorophyll 'a' and 'b' as compared to control when herbage of wheat cultivars collected at the tillering stage was soil incorporated (Figure 3C). Reduction in total chlorophyll contents of lambsquarter seedling to the tune of $58 \%$ was observed when herbage of Millat-2011collected at the anthesis stage was soil incorporated (Figure 3C). This treatment combination was significantly $(p \leq 0.05)$ different from the reduction in total chlorophyll realized under the incorporation of the maturity stage herbage of AARI-2011 but was similar to the herbage of Lasani-2008 and Faisalabad-2008 (Figure 3C). Maximum reduction in total chlorophyll $(87 \%)$ was noticed when the herbage of wheat cultivar AARI-2011 collected at the maturity stage was soil incorporated that was statistically at par with Millat-2011 (Figure 3C). Interactive effect between wheat cultivars and stages of herbage collection was nonsignificant $(p \leq 0.05)$ for phenolic contents; however, the influence of wheat cultivars and stages of herbage collection was significant in this regard (Table 3). Phenolic content remained similar to control under the incorporation of the tillering stage herbage of wheat cultivars, while phenolic contents increased by the incorporation of herbage of anthesis and maturity stage of wheat. Maximum increase $(30 \%)$ in phenolic contents of lambsquarter seedlings was observed when herbage of the maturity stage was soil incorporated that was statistically at par with the anthesis stage herbage incorporation (Table 5). Significant $(p \leq 0.05)$ increase in phenolic contents was noticed for lambsquarter seedlings that were grown in pots amended with herbage of Millat-2011, AARI-2011 and Lasani-2008.

\section{Lipid peroxidation and activity of enzymatic antioxidant}

The MDA (malondialdehyde) contents of lambsquarter were increased by 143 and 243\% over control when herbage collected at anthesis and maturity stage of wheat was soil incorporated. Tillering stage herbage had no effect on MDA contents of lambsquarter (Table 6). Interactive effect between wheat cultivar and stages of herbage collection was nonsignificant $(p \leq 0.05)$ for activities of most enzymatic antioxidants of lambsquarter except SOD activity. Activity of SOD (superoxide dismutase) significantly varied $(p \leq 0.05)$ among wheat cultivars as a function of herbage collection. Maximum SOD activity (490 and 350 Units g $^{-1}$ protein) of lambsquarter was observed for the tillering stage herbage of AARI-2011 and Lasani-2008, respectively, as compared to control (57 Units $\mathrm{g}^{-1}$ protein) (Figure 4). Herbage incorporation of wheat cultivars like Lasani-2008 and Faisalabad2008 collected at the maturity stage recorded minimum stimulation of SOD activity (130 and $69 \%$ ) of lambsquarter, respectively, over control (Figure 4). Significant ( $p \leq 0.05$ ) stimulation of SOD activity of lambsquarter seedling was also observed for the maturity stage herbage of AARI-2011 that was similar 

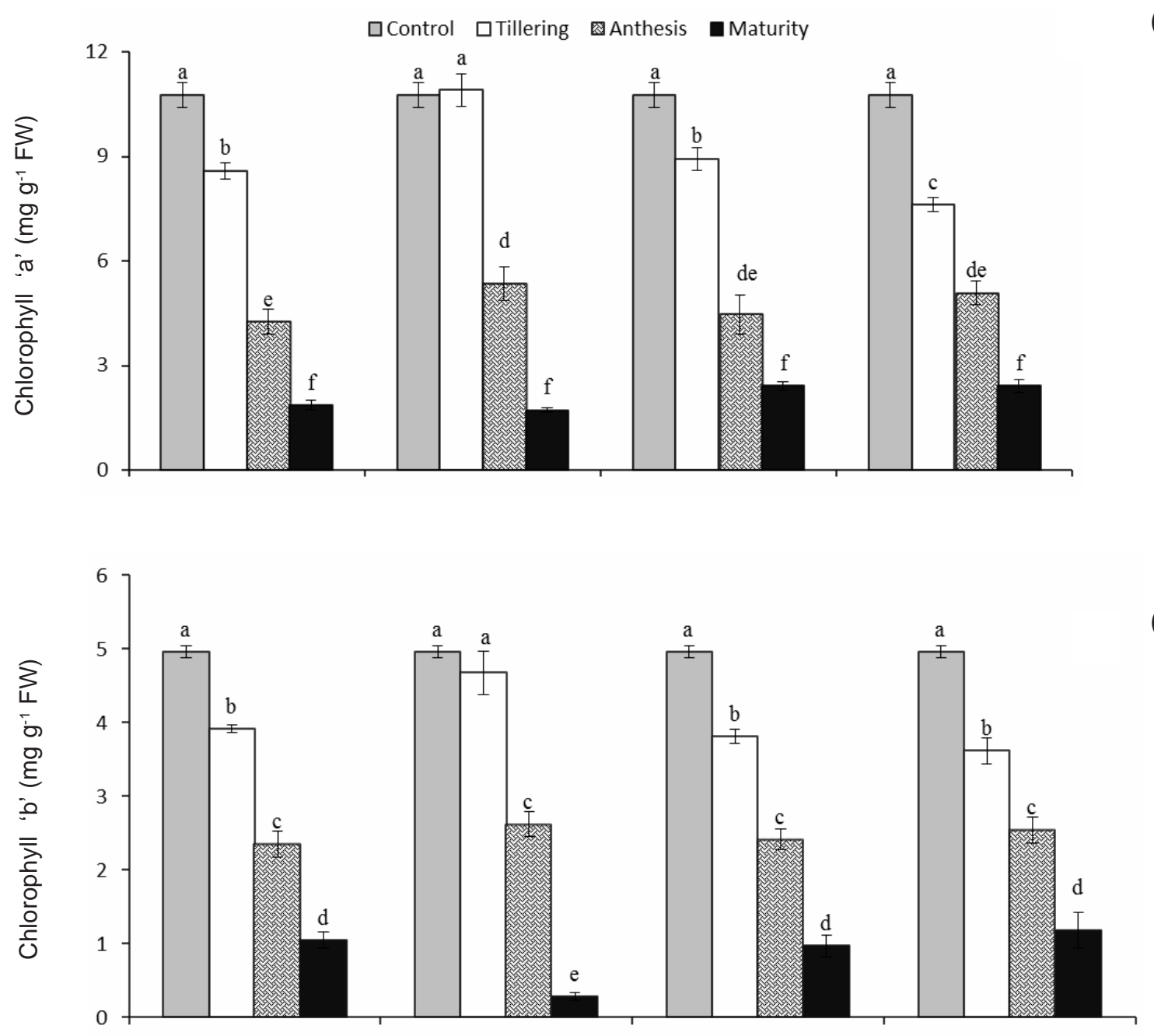

(B)

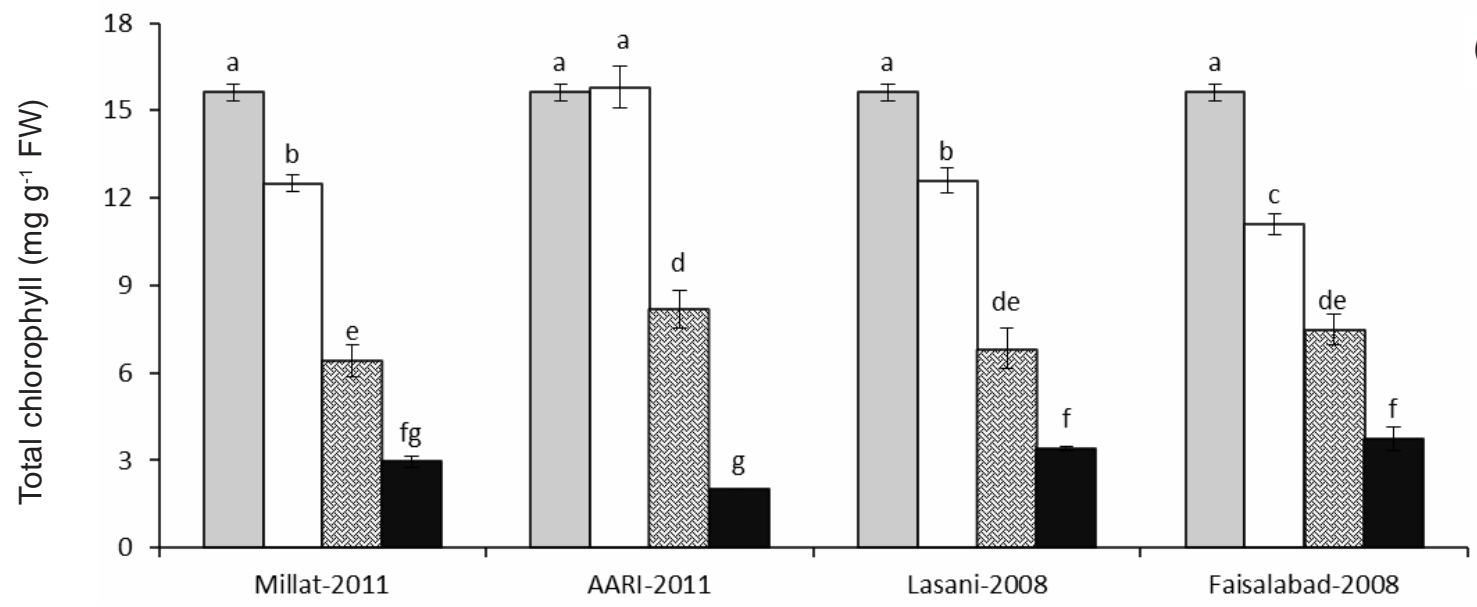

Figure 3 - Influence of soil incorporation of wheat herbage collected at different growth stages on (A) chlorophyll 'a', (B) chlorophyll 'b' and (C) total chlorophyll contents of lambsquarter. Vertical bars above the means denote the standard error of four replicates. Interaction means not sharing a letter in common differ significantly at $5 \%$ probability test by LSD test. Critical value for comparison is (A) 0.960, (B) 0.426, (C) 1.202. 
Table 5 - Influence of soil incorporation of wheat herbage of different growth stages on total soluble phenolic contents of lambsquarter

\begin{tabular}{|l|c|c|c|c|c|}
\hline \multicolumn{7}{|c|}{ Total phenolic $\left(\mathrm{mg} \mathrm{g}^{-1} \mathrm{FW}\right)$} \\
\hline \multicolumn{1}{|c|}{ Cultivar } \\
\hline Growth stages & Millat-2011 & AARI-2011 & Lasani-2008 & Faisalabad-2008 & Mean \\
\hline Control & $31.71^{\text {n.s }}$ & 31.71 & 31.71 & 31.71 & $31.71 \mathrm{C}$ \\
\hline Tillering & 33.22 & 30.83 & 34.46 & 31.90 & $32.60 \mathrm{C}$ \\
\hline Anthesis & 41.92 & 42.65 & 35.80 & 35.07 & $38.86 \mathrm{~B}$ \\
\hline Maturity & 45.15 & 45.95 & 37.39 & 37.37 & $41.47 \mathrm{AB}$ \\
\hline Mean & $38.00 \mathrm{~A}$ & $37.79 \mathrm{~A}$ & $34.84 \mathrm{AB}$ & $34.01 \mathrm{~B}$ & \\
\hline
\end{tabular}

$\mathrm{C}=$ wheat cultivars, $\mathrm{G} . \mathrm{S}=$ growth stages, $\mathrm{C} \times \mathrm{G} . \mathrm{S}=$ wheat cultivars $\times$ growth stages, n.s= nonsignificant. Each number is average of four replicates. Main effect means not sharing a letter in common differ significantly at 5\% probability level by LSD test.

Table 6 - Influence of soil incorporation of wheat herbage of different growth stages on POX, catalase, soluble protein and MDA of lambsquarter

\begin{tabular}{|c|c|c|c|c|c|}
\hline \multicolumn{6}{|c|}{ Cultivar } \\
\hline \multicolumn{6}{|c|}{ POX ( $\mu$ mol min $^{-1} \mathrm{~g}^{-1}$ protein $)$} \\
\hline Growth stages & Millat-2011 & AARI-2011 & Lasani-2008 & Faisalabad-2008 & Mean \\
\hline Control & $35.34^{\text {n.s }}$ & 35.34 & 35.34 & 35.34 & $35.34 \mathrm{~A}$ \\
\hline Tillering & 17.48 & 28.55 & 32.93 & 22.81 & $25.44 \mathrm{~B}$ \\
\hline Anthesis & 14.99 & 16.03 & 17.83 & 16.90 & $16.44 \mathrm{C}$ \\
\hline Maturity & 14.38 & 5.28 & 10.60 & 10.77 & $10.26 \mathrm{D}$ \\
\hline Mean & 20.55 & 21.30 & 24.18 & 21.46 & \\
\hline \multicolumn{3}{|c|}{$\mathrm{LSD} \triangle 0.05$} & \multicolumn{3}{|c|}{$\mathrm{C}=\mathrm{n} . \mathrm{s}, \mathrm{G} . \mathrm{S}=4.782, \mathrm{C} \times \mathrm{G} . \mathrm{S}=\mathrm{n} . \mathrm{s}$} \\
\hline \multicolumn{6}{|c|}{ CAT ( $\mu$ mol $\min ^{-1} \mathrm{~g}^{-1}$ protein $)$} \\
\hline Control & $362.15^{\text {n.s }}$ & 362.15 & 362.15 & 362.15 & $362.15 \mathrm{~A}$ \\
\hline Tillering & 141.41 & 167.66 & 208.91 & 103.30 & $155.32 \mathrm{~B}$ \\
\hline Anthesis & 84.06 & 116.32 & 130.90 & 94.97 & $106.56 \mathrm{BC}$ \\
\hline Maturity & 85.34 & 16.89 & 32.15 & 49.14 & $45.88 \mathrm{C}$ \\
\hline Mean & 168.24 & 165.75 & 183.53 & 152.39 & \\
\hline \multicolumn{3}{|c|}{$\mathrm{LSD} \triangle 0.05$} & \multicolumn{3}{|c|}{$\mathrm{C}=\mathrm{n} . \mathrm{s}, \mathrm{G} . \mathrm{S}=70.40, \mathrm{C} \times \mathrm{G} . \mathrm{S}=\mathrm{n} . \mathrm{s}$} \\
\hline \multicolumn{6}{|c|}{ Soluble proteins $\left(\mathrm{mg} \mathrm{g}^{-1} \mathrm{FW}\right)$} \\
\hline Control & $14.14^{\mathrm{n} . \mathrm{s}}$ & 14.14 & 14.14 & 14.14 & $14.14 \mathrm{~A}$ \\
\hline Tillering & 6.69 & 7.59 & 10.40 & 5.90 & $7.64 \mathrm{~B}$ \\
\hline Anthesis & 5.49 & 7.02 & 6.37 & 6.42 & $6.33 \mathrm{BC}$ \\
\hline Maturity & 5.57 & 2.06 & 4.32 & 4.97 & $4.23 \mathrm{C}$ \\
\hline Mean & 7.97 & 7.70 & 8.80 & 7.86 & \\
\hline \multicolumn{3}{|c|}{$\mathrm{LSD} \triangle 0.05$} & \multicolumn{3}{|c|}{$\mathrm{C}=\mathrm{n} . \mathrm{s}, \mathrm{G} . \mathrm{S}=2.132, \mathrm{C} \times \mathrm{G} . \mathrm{S}=\mathrm{n} . \mathrm{s}$} \\
\hline \multicolumn{6}{|c|}{$\operatorname{MDA}\left(\mathrm{nm} \mathrm{g}^{-1} \mathrm{FW}\right)$} \\
\hline Control & $0.23^{\mathrm{n} . \mathrm{s}}$ & 0.23 & 0.23 & 0.23 & $0.23 \mathrm{C}$ \\
\hline Tillering & 0.26 & 0.53 & 0.30 & 0.35 & $0.36 \mathrm{C}$ \\
\hline Anthesis & 0.47 & 0.88 & 0.54 & 0.36 & $0.56 \mathrm{~B}$ \\
\hline Maturity & 0.81 & 0.93 & 0.91 & 0.42 & $0.77 \mathrm{~A}$ \\
\hline Mean & $0.44 \mathrm{~B}$ & $0.64 \mathrm{~A}$ & $0.49 \mathrm{AB}$ & $0.34 \mathrm{~B}$ & \\
\hline \multicolumn{3}{|c|}{$\mathrm{LSD} \triangle 0.05$} & \multicolumn{3}{|c|}{$\mathrm{C}=\mathrm{n} . \mathrm{s}, \mathrm{G} . \mathrm{S}=0.191, \mathrm{C} \times \mathrm{G} . \mathrm{S}=\mathrm{n} . \mathrm{s}$} \\
\hline
\end{tabular}

$\mathrm{C}=$ wheat cultivars, G.S $=$ growth stages, $\mathrm{C} \times \mathrm{G} . \mathrm{S}=$ wheat cultivars $\times$ growth stages, n.s $=$ nonsignificant. Each number is average of four replicates and represents 20 seeds of test specie, Main effect means not sharing a letter in common differ significantly at 5\% probability level by LSD test. 
to the stimulation of SOD activity recorded in pots where herbage of the same cultivar collected at the anthesis stage was soil incorporated. Soil incorporation of tillering, anthesis and maturity stage herbage inhibited the POX (peroxidase) activity of lambsquarter seedlings by 28,53 and $70 \%$, respectively, over control (Table 6). Maximum inhibition of CAT (catalase) activity of lambsquarter was observed in pots amended with maturity stage herbage of wheat that was at par with the anthesis stage herbage incorporation. Moreover, inhibition of CAT activity remained statistically at par when wheat herbage of tillering and anthesis stage was soil incorporated (Table 6). Minimum soluble protein contents of lambsquarter were observed in response to the incorporation of maturity stage herbage of wheat that was at par with anthesis stage herbage amended soil (Table 6). Soluble protein contents of lambsquarter were lowered to an upper limit of $70 \%$ when the maturity stage herbage of wheat was soil incorporated, and were statistically at par with the anthesis stage herbage incorporation.

\section{Correlation between variables}

Correlation analyses revealed a positive and strong relationship between final emergence and seedling dry biomass of lambsquarter for all experimental treatments except pots amended with the anthesis stage herbage of Lasani-2008 and Faisalabad-2008. Leaf chlorophyll content manifested a strong and positive correlation with seedling fresh biomass that was true for all experimental treatments except for pots amended with the tillering stage herbage of Lasani-2008 and Faisalabad-2008. A negative correlation was found between total chlorophyll and soluble phenolic contents of lambsquarter growing in pots where the herbage of wheat cultivar collected at different growth stages was soil incorporated (Table 7).

Activity of SOD was negatively correlated with shoot length of lambsquarter under the incorporation of herbage collected at different growth stages of all wheat cultivars, while this relationship was nonsignificant for the tillering stage herbage of Millat-2011 and AARI-2011 (Table 8). A positive and strong correlation was noticed for activities of POX, CAT, and protein with shoot length of lambsquarter in pots where anthesis and maturity stage herbage of wheat were incorporated. Nevertheless, such an association for POX, CAT and protein was nonsignificant for the tillering stage herbage of all wheat cultivars (Table 8).

Activity of SOD had a strong and negative correlation with root length of lambsquarter

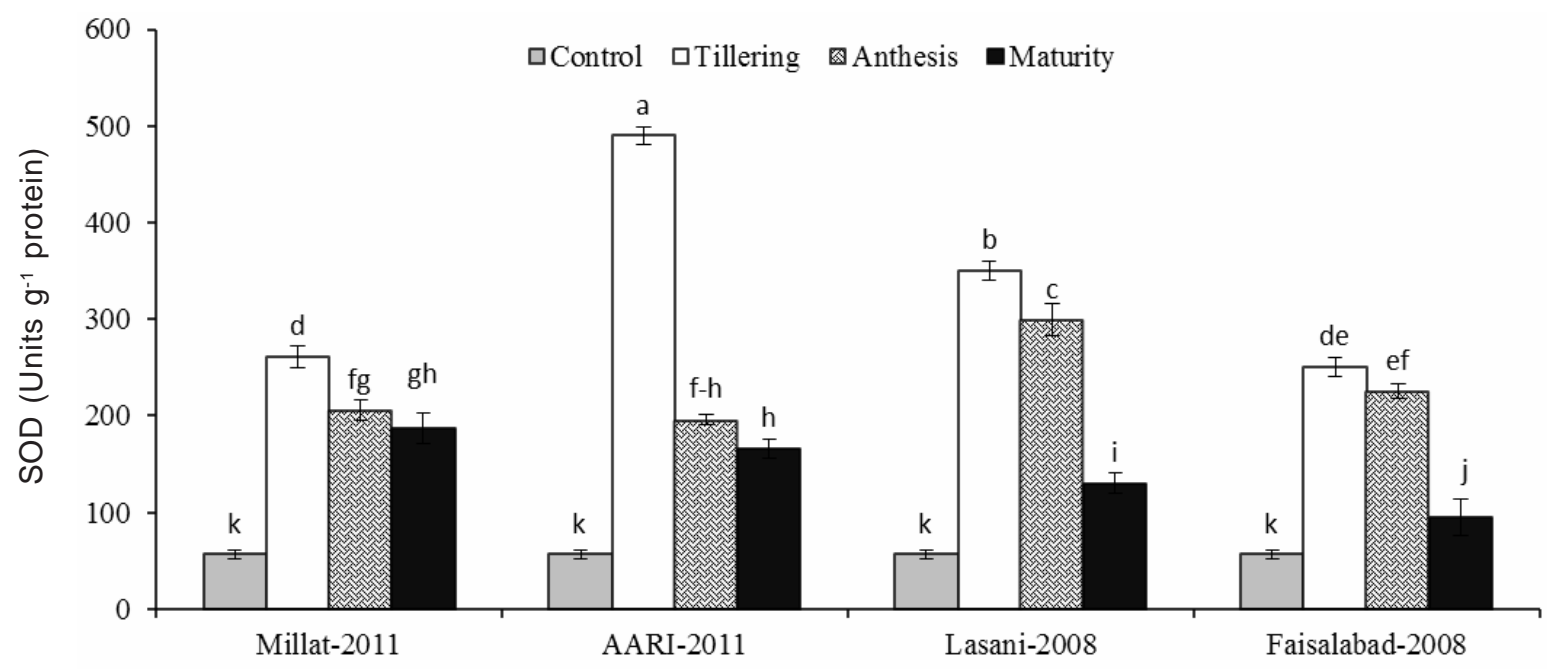

Figure 4 - Influence of soil incorporation of wheat herbage of different growth stages on SOD activity of lambsquarter. Vertical bars above the means denote the standard error of four replicates. Interaction means not sharing a letter in common differ significantly at $5 \%$ probability test by LSD test. Critical value for comparision is 29.813 . 
Table 7 - Correlation analyses showing strength of association between different variables

\begin{tabular}{|c|c|c|c|c|c|}
\hline \multirow{2}{*}{$\mathrm{X}$-variable } & \multirow{2}{*}{ Y-variable } & \multirow{2}{*}{ Cultivars } & \multicolumn{3}{|c|}{ Growth stages } \\
\hline & & & Tillering & Anthesis & Maturity \\
\hline \multirow{4}{*}{ FEP } & \multirow{4}{*}{ SDW } & Millat-2011 & $0.647 *$ & $0.681^{*}$ & $0.912 * * *$ \\
\hline & & AARI-2011 & $0.765^{* *}$ & 0.693* & $0.965^{* * *}$ \\
\hline & & Lasani-2008 & 0.689* & $0.166^{\text {n.s. }}$ & $0.914 * * *$ \\
\hline & & Faisalabad-2008 & $0.677 *$ & $0.386^{\text {n.s. }}$ & $0.914 * * *$ \\
\hline \multirow{4}{*}{ Chlorophyll } & \multirow{4}{*}{ SFW } & Millat-2011 & 0.656* & $0.949 * * *$ & $0.990 * * *$ \\
\hline & & AARI-2011 & 0.687* & $0.959 * * *$ & $0.990 * * *$ \\
\hline & & Lasani-2008 & $0.421^{\text {n.s. }}$ & $0.955 * * *$ & $0.989 * * *$ \\
\hline & & Faisalabad-2008 & $0.577^{\text {n.s. }}$ & $0.978 * * *$ & $0.988 * * *$ \\
\hline \multirow{4}{*}{ Chlorophyll } & \multirow{4}{*}{$\begin{array}{c}\text { Total soluble } \\
\text { phenol }\end{array}$} & Millat-2011 & $-0.629 *$ & $-0.854 * *$ & $-0.735^{*}$ \\
\hline & & AARI-2011 & $-0.289^{\text {n.s. }}$ & $-0.904 * * *$ & $-0.714^{*}$ \\
\hline & & Lasani-2008 & $-0.611^{*}$ & $-0.643 *$ & $-0.621 *$ \\
\hline & & Faisalabad-2008 & $-0.074^{\text {n.s. }}$ & $-0.635^{*}$ & $-0.667 *$ \\
\hline
\end{tabular}

${ }^{*} p<0.05, * * p<0.01, * * * p<0.001,{ }^{\text {n.s }}$ Non significant.

under the incorporation of wheat herbage of different growth stages, and this was true for all wheat cultivars. However; a negative but nonsignificant correlation was noticed for pots amended with the tillering stage herbage of Millat-2011 and Faisalabad-2008. There was a strong and positive correlation of POX and CAT with root length of lambsquarter for pots amended with herbage collected at different growth stages of all wheat cultivars. However, such relationship of POX was nonsignificant for the tillering stage herbage incorporation of Lasani-2008 and Faisalabad-2008 and CAT for Millat-2011 and AARI-2011. Likewise, protein contents were also strongly and positively correlated with root length of lambsquarter in pots amended with herbage collected at different growth stages of all wheat cultivars, except for pots amended with the tillering stage herbage of Millat-2011 (Table 8).

The SOD activity was strongly and negatively correlated with seedling dry biomass of lambsquarter under the incorporation of herbage collected at anthesis and maturity stage of all wheat cultivars. However, such an association was nonsignificant for all wheat cultivars when compared to the tillering stage herbage. Activities of POX and CAT were strongly and positively correlated with seedling dry biomass of lambsquarter for pots amended with herbage collected at different growth stages of all wheat cultivars. Likewise, protein contents were strongly and positively correlated with seedling dry biomass of lambsquarter under the influence of anthesis and maturity stage herbage incorporation of all wheat cultivars. However, for the tillering stage herbage such correlation was only significant for Millat-2011 and Faisalabad-2008 (Table 8).

The differential allelopathic inhibition of lambsquarter seedling by wheat herbage in the present study can be attributed to differences for type and concentration of phytotoxins present in four wheat cultivars at different growth stages. Numerous phytotoxic compounds or allelochemicals produced by wheat are phenolic acids, hydroximic acid, and short and long chain fatty acids (Wu et al., 2001; Ma, 2005). These compounds are phytotoxic for weeds as well as other crop plants (Wu et al., 2001). Allelopathic potential varies among cultivars of the same species (Anjum \& Bajwa, 2010), plant parts (Qasem \& Foy, 2001), and also with plant age (Wu et al., 2000), and phenological and environmental conditions (Rice, 1984). Results presented here have demonstrated that herbage of all four wheat cultivars collected at different growth stages contained different concentrations of phenolic compounds which increased with growth stages (Table 1). The degree of inhibition strongly corresponded to concentrations of phytotoxic compounds released in the soil amended with wheat herbage of different growth stages. The emergence attributes of lambsquarter were inhibited by incorporation 
of wheat herbage collected at different growth stages. Our results have revealed that soil amended with wheat herbage collected at anthesis and maturity stage have significantly inhibited the emergence of lambsquarter (Table 3; Figure 1). Such inhibition of seed emergence may be due to the exposure of seeds to released phytotoxic compounds from the wheat herbage. These phytotoxic compounds alter the biochemical and physiological reactions in the cell membrane ultrastructure, membrane permeability and integrity, synthesis of certain compounds and enzymatic activities during germination (Gniazdowska \& Bogatek, 2005). Speed of emergence is an important indicator of the normal seedling development and its suppression by wheat herbage was an indication of the inhibitory activity of allelochemicals released by the decomposing wheat tissues over the course of time. Seedling growth of lambsquarter was significantly suppressed under the influence of wheat herbage collected at different growth stages. Suppression in seedling growth of lambsquarter might be due to the inhibitory action of allelochemicals either by creatingphysiological drought, prevention of cell division and elongation, or by reduction of stimulatory growth (Al-Wakeel et al., 2007; Zhang et al., 2010). Additionally, these chemicals may cause alteration in the cell membrane structure and permeability which results in several other cross-stress responses due to lipid peroxidation (Zeng et al., 2001) and ROS (reactive oxygen species) damage (Khaliq et al., 2012). The increased activity of antioxidant enzymes as observed in the present study affirms this notion. Oxidative stress can alter the membrane permeability and fluxes across the plasma membrane, causing enzyme activation, oxidative stress and root uptake of nutrients. Plants overcome these changes by the activation of an antioxidant system and regulate the enzyme activity (Bogatek \& Gniazdowska, 2007).

Chlorophyll contents in the leaves of lambsquarter were decreased under the influence of anthesis and maturity stage herbage incorporation of all four wheat cultivars. A decline in chlorophyll content may be due to the phytotoxic activity of the released compounds. Decline in chlorophyll contents was highly associated with the production of phenolic compounds (Table 5). Recently, Sumbele et al. (2012), while working with 49 plant species sampled from Greece and Australia, have reported that photosynthetic capacity was negatively associated with leaf phenolic contents. Wheat phytotoxic compounds might have inhibited chlorophyll content in lambsquarter seedlings either by interfering with the biosynthesis of photosynthetic pigments or by enhancing their degradation by inducing oxidative stress via generation of reactive oxygen species or both of these. The substantial proof of this finding is supported by the significantly lower chlorophyll contents and increased activities of enzymatic antioxidants observed during the course of the present study.

The antioxidant enzymes are often activated under stress conditions. SOD activity of lambsquarter increased when grown in soil amended with wheat herbage collected at the tillering stage, which was helpful in reducing the adverse effects of wheat phytotoxic compounds originating from superoxidase radicles $\left(\mathrm{O}_{2}^{-}\right)$. The SOD is a metalo enzyme involved in the degradation of superoxidase radicles $\left(\mathrm{O}_{2}^{-}\right)$(Apel \& Hert, 2004). The stimulation of SOD activity removes the $\mathrm{O}_{2}{ }^{-}$ contents and produces $\mathrm{H}_{2} \mathrm{O}_{2}$ and $\mathrm{O}_{2}$. On the other hand, increased activity of POX and CAT is helpful to scavenge $\mathrm{H}_{2} \mathrm{O}_{2}$ and $\mathrm{O}_{2}$ into $\mathrm{H}_{2} \mathrm{O}$ and $\mathrm{O}_{2}$. Under lower concentrations of phytotoxic compounds, free radicals are easily alleviated by scavengers due to less stress conditions (Zhang et al., 2010). In addition, the MDA contents did not change much over the control and this may be due to higher SOD activity, which reduced $\mathrm{O}_{2}^{-}$contents. Zhang et al. (2010) have found that higher SOD activity has reduced the membrane lipid peroxidation. The SOD, POX and CAT activities of lambsquarter were however lower in pots where anthesis and maturity stage wheat herbage were incorporated. It may be because of a higher concentration of a phytotoxic compound in wheat herbage of anthesis and maturity stage, as evident from higher phenolic contents. Huang et al. (2010) have also reported that increasing the concentration of allelochemicals has inhibited the activity of 
Table 8 - Correlation analyses showing strength of association between antioxidant and seedling growth

\begin{tabular}{|c|c|c|c|c|c|}
\hline \multirow{2}{*}{$\mathrm{X}$-variable } & \multirow{2}{*}{ Y-variable } & \multirow{2}{*}{ Cultivar } & \multicolumn{3}{|c|}{ Growth stages } \\
\hline & & & Tillering & Anthesis & Maturity \\
\hline \multirow{4}{*}{ SOD } & \multirow{4}{*}{ SL } & Millat-2011 & $-0.032^{\text {n.s. }}$ & $-0.947 * * *$ & $-0.989 * * *$ \\
\hline & & AARI-2011 & $-0.560^{\text {n.s. }}$ & $-0.962 * * *$ & $-0.991 * * *$ \\
\hline & & Lasani-2008 & $-0.761 *$ & $-0.945 * * *$ & $-0.984 * * *$ \\
\hline & & Faisalabad-2008 & $-0.708^{*}$ & $-0.968 * * *$ & $-0.959 * * * *$ \\
\hline \multirow{4}{*}{ POX } & \multirow{4}{*}{ SL } & Millat-2011 & $0.402^{\text {n.s. }}$ & $0.911 * * *$ & $0.963 * * *$ \\
\hline & & AARI-2011 & $0.382^{\text {n.s. }}$ & $0.910 * * *$ & $0.923 * * *$ \\
\hline & & Lasani-2008 & $0.518^{\text {n.s. }}$ & $0.908 * * *$ & $0.948 * * *$ \\
\hline & & Faisalabad-2008 & $0.553^{\text {n.s. }}$ & $0.909 * * *$ & $0.948 * * *$ \\
\hline \multirow{4}{*}{ CAT } & \multirow{4}{*}{ SL } & Millat-2011 & $0.159^{\text {n.s. }}$ & $0.716 *$ & $0.774 * *$ \\
\hline & & AARI-2011 & $0.346^{\text {n.s. }}$ & $0.715^{*}$ & $0.831^{* *}$ \\
\hline & & Lasani-2008 & $0.391^{\text {n.s. }}$ & $0.716^{*}$ & $0.809 * *$ \\
\hline & & Faisalabad-2008 & $0.334^{\text {n.s. }}$ & $0.716^{*}$ & $0.804 * *$ \\
\hline \multirow{4}{*}{ Protein } & \multirow{4}{*}{ SL } & Millat-2011 & $0.099^{\text {n.s. }}$ & $0.728^{*}$ & $0.768^{*}$ \\
\hline & & AARI-2011 & $0.322^{\text {n.s. }}$ & $0.711^{*}$ & $0.871 * *$ \\
\hline & & Lasani-2008 & $0.466^{\text {n.s. }}$ & $0.752^{*}$ & $0.822 * *$ \\
\hline & & Faisalabad-2008 & $0.396^{\text {n.s. }}$ & $0.719 *$ & $0.806 * *$ \\
\hline \multirow{4}{*}{ SOD } & \multirow{4}{*}{ RL } & Millat-2011 & $-0.581^{\text {n.s. }}$ & $-0.972 * * *$ & $-0.973 * * *$ \\
\hline & & AARI-2011 & $-0.747^{*}$ & $-0.985 * * *$ & $-0.995 * * *$ \\
\hline & & Lasani-2008 & $-0.883 * *$ & $-0.953 * * *$ & $-0.989 * * *$ \\
\hline & & Faisalabad-2008 & $-0.376^{\text {n.s.. }}$ & $-0.986 * * *$ & $-0.976 * * *$ \\
\hline \multirow{4}{*}{ POX } & \multirow{4}{*}{ RL } & Millat-2011 & $0.629 *$ & $0.966 * * *$ & $0.932 * * *$ \\
\hline & & AARI-2011 & $0.795 * *$ & $0.922 * * *$ & $0.978 * * *$ \\
\hline & & Lasani-2008 & $0.543^{\text {n.s. }}$ & $0.812^{* *}$ & $0.966 * * *$ \\
\hline & & Faisalabad-2008 & $0.498^{\text {n.s. }}$ & $0.935 * * *$ & $0.969 * * *$ \\
\hline \multirow{4}{*}{ CAT } & \multirow{4}{*}{ RL } & Millat-2011 & $0.475^{\text {n.s. }}$ & $0.826 * *$ & $0.806 * *$ \\
\hline & & AARI-2011 & $0.519^{\text {n.s. }}$ & $0.788 * *$ & $0.867 * *$ \\
\hline & & Lasani-2008 & $0.623 *$ & $0.767 *$ & $0.857 * *$ \\
\hline & & Faisalabad-2008 & $0.781^{* *}$ & $0.828 * *$ & $0.844^{* *}$ \\
\hline \multirow{4}{*}{ Protein } & \multirow{4}{*}{ RL } & Millat-2011 & $0.562^{\text {n.s. }}$ & $0.832 * *$ & $0.840 * *$ \\
\hline & & AARI-2011 & $0.723 *$ & $0.800 * *$ & $0.911 * * *$ \\
\hline & & Lasani-2008 & 0.691* & $0.788 * *$ & $0.869 * *$ \\
\hline & & Faisalabad-2008 & 0.733* & $0.835 * *$ & $0.856 * *$ \\
\hline \multirow{4}{*}{ SOD } & & Millat-2011 & $-0.228^{\text {n.s. }}$ & $-0.910 * * *$ & $-0.954 * * *$ \\
\hline & SDW & AARI-2011 & $-0.105^{\text {n.s. }}$ & $-0.956 * * *$ & $-0.976 * * *$ \\
\hline & SDV & Lasani-2008 & $-0.104^{\text {n.s. }}$ & $-0.948 * * *$ & $-0.973 * * *$ \\
\hline & & Faisalabad-2008 & $-0.329^{\text {n.s. }}$ & $-0.943 * * *$ & $-0.944 * * *$ \\
\hline & & Millat-2011 & 0.603* & $0.997 * * *$ & $0.967 * * *$ \\
\hline $\mathrm{POX}$ & SDW & AARI-2011 & $0.660 *$ & $0.958 * * *$ & $0.995 * * *$ \\
\hline PUX & SDW & Lasani-2008 & $0.919 * * *$ & $0.756 *$ & $0.994 * * *$ \\
\hline & & Faisalabad-2008 & 0.686* & $0.958 * * *$ & $0.991^{* * *}$ \\
\hline & & Millat-2011 & $0.676 *$ & $0.916^{* * *}$ & $0.869 * *$ \\
\hline CAT & SDW & AARI-2011 & $0.643 *$ & $0.861 * *$ & $0.921 * * *$ \\
\hline CA1 & SDW & Lasani-2008 & $0.466^{\text {n.s. }}$ & $0.797 * *$ & $0.909 * * *$ \\
\hline & & Faisalabad-2008 & $0.784 * *$ & $0.898 * * *$ & $0.902 * * *$ \\
\hline & & Millat-2011 & $0.724 *$ & $0.932 * * *$ & $0.904 * * *$ \\
\hline Protein & SDW & AARI-2011 & $0.381^{\text {n.s. }}$ & $0.881 * *$ & $0.958 * * *$ \\
\hline Protein & SDV & Lasani-2008 & $0.453^{\text {n.s. }}$ & $0.794 * *$ & $0.933^{* * *}$ \\
\hline & & Faisalabad-2008 & $0.704 *$ & $0.921 * * *$ & $0.917 * * *$ \\
\hline
\end{tabular}

$* p<0.05, * * p<0.01, * * * p<0.001,{ }^{\text {n.s }}$ Non significant. 
SOD. The allelochemicals have induced oxidative stress in the target plant tissues and hampered the antioxidant mechanism (Aenavoli et al., 2006). It seems that phytotoxic compounds in wheat herbage have caused oxidative stress by stimulating lipid peroxidation in lambsquarter seedlings as higher MDA contents were recorded.

Organic and inorganic compounds contained in plant herbage have an important role in determining the phytotoxicity against target species. Inhibition by the herbage incorporation depends on herbage quality, degree of decomposition, nutrient status and microbial activity (Rice, 1984; Inderjit et al., 1996). Herbage of all wheat cultivars collected at different growth stages were significantly different regarding carbon and nitrogen contents, and carbon/nitrogen ratio. Herbage collected at anthesis and maturity stage of wheat cultivars had higher carbon and nitrogen contents as compared to the tillering stage. Herbage collected at anthesis and maturity stage of wheat cultivar AARI-2011 and Lasani-2008 had maximum carbon (381 and $376 \mathrm{mg} \mathrm{g}^{-1}$ ) and nitrogen (4.53 and $4.40 \mathrm{mg} \mathrm{g}^{-1}$ ) contents (Table 2). However, herbage collected at tillering stage decomposed rapidly as compared to the anthesis and maturity stage herbage. The nature of the incorporated residue affects the microbial activity and cycling and decomposition of carbon and other nutrient elements (Sajjad et al., 2002). Soil microorganisms decompose these compounds (Inderjit, 2005; Jilani et al., 2008) and improve their activity by returning the straw of cover crops in soil and use organic carbon as carbon and as an energy source (Hai-Ming et al., 2014). The addition of plant residue in the soil increases the microbial activity, and population (Ruiyu et al., 2007) that utilizes the nitrogen present in the soil and consequently causes temporary nitrogen deficiency (Bonanomi et al., 2011). Therefore it can be suspected that the observed inhibitory effect after addition of wheat herbage to the soil may be caused by nitrogen depletion rather than release of phytotoxic compounds. However, in the present study the available nitrogen was higher in herbage amended soil as compared to unamended soil. Our results are in line with Sodaeizadeh et al. (2010), who have concluded that the negative effect of Peganum harmala amended soil on growth of Avena fatua and Convolvulus arvensis is not due to nitrogen immobilization but to the presence of allelochemicals in the soil. Bonanomi et al. (2011) have found that inhibitory effects of plant litter on Lepdium sativum were due to phytotoxicity, rather than $\mathrm{N}$ mobilization. Furthermore, the effect of herbage decomposition on the soil $\mathrm{pH}$ varied during the course of the study (Table 2). This may be due to the differences in herbage composition and release of carbon and nitrogen contents. Addition of wheat herbage of different growth stages has increased the nitrogen contents and $\mathrm{pH}$ of the soil during the $1^{\text {st }}$ week of incorporation (Table 2). Numerous studies have reported that the mineralization of carbon and nitrogen is pH-dependent (Marschner \& Kalbitz, 2003; Kemmitt et al., 2006). Higher pH increases mineralization due to enhanced activity and survival of microorganisms and is also due to more solubility of dissolved organic compounds (Butterly et al., 2013).

The present study has concluded that the production of allelochemicals is variable among wheat cultivars and their growth stages. Obtained results provide substantial proof that herbage collected at different stages of wheat cultivars manifested a differential allelopathic potential against lambsquarter's emergence and seedling growth. The retardation of lambsquarter seedling growth by wheat herbage was associated with enhanced lipid peroxidation and reduction in chlorophyll contents. More allelochemicals were produced at later growth stages (anthesis and maturity) of wheat as compared to the early growth stage (tillering). Anthesis and maturity stage herbage of wheat cultivars AARI-2011 and Lasani-2008 were more phytotoxic than Millat-2011 and Faisalabad2008. Moreover, the tillering stage herbage of all wheat cultivars had a stimulatory effect on emergence, seedling growth and biochemical attributes of lambsquarter. These important findings warrant the need to return the maturity stage wheat herbage into soil instead of its removal from the field for effective suppression of this weed and nutrient recycling.

Planta Daninha, Viçosa-MG, v. 33, n. 4, p. 643-662, 2015 


\section{ACKNOWLEDGMENT}

The financial support from the Higher Education Commission, Government of Pakistan, under the indigenous $5000 \mathrm{Ph}$. D fellowship program is gratefully acknowledged.

\section{LITERATURE CITED}

AENAVOLI, M. R. et al. The inhibitory effects of coumarin on the germination of durum wheat (Triticum turgidum) ssp. durum, cv. J. Chem. Ecol., v. 32, n. 2, p. 489-506, 2006.

ALBUQUERQUE, M. B. D. et al. Allelopathy, an alternative tool to improve cropping systems. A Review. Agron.

Sustain. Dev., v. 31, n. 2, p. 379-395, 2011.

AL-WAKEEL, S. A. M. et al. Allelopathic effects of Acacia nilotica leaf residue on Pisum sativum L. Allelop. J., v. 19, n. 2, p. 411-422, 2007.

AN, M. et al. Mathematical modelling of allelopathy: II. The dynamics of allelochemicals from living plants in the environment. Ecol. Model., v. 161, n. 1, p. 53-66, 2003.

ANJUM, T.; BAJWA, R. The effect of sunflower leaf extracts on Chenopodium album L. in wheat fields in Pakistan. Crop Protec., v. 26, n. 9, p. 1390-1394, 2007.

ANJUM, T.; BAJWA, R. Sunûower allelochemicals adversely affect wheat yield. Nat. Prod. Res., v. 24, n. 9, p. 825-837, 2010.

ASSOCIATION OF OFFICAL SEED ANALYSIS - AOSA. Seed vigor hand testing handbook. Springfield, Illinois: 1983. (Contribution, 32)

ASSOCIATION OF OFFICAL SEED ANALYSIS - AOSA. Rules for testing seeds. J. Seed Technol., v. 12, n. 3, p. 1112, 1990.

APEL, K.; HIRT, H. Reactive oxygen species metabolism, oxidative stress, a signal transduction. Ann. Rev. Plant. Biol., v. 55, n. 1, p. 373-399, 2004.

ARNON, D. I. Copper enzymes in isolated chloroplast. I. Polypenol oxidase in Beta vulgaris. Plant Physiol., v. 24, n. 1, p. 1-15, 1994.

BAILLY, C. et al. Changes in malondialdehyde contents and in superoxide dismutase, catalase, glutathione reductase activities in sunflower seeds related to accelerated seed aging. Physiol. Plant., v. 97, n. 1, p. 104-110, 1996.

BAUCOM, R. S. A herbicide defense trait that is distinct from resistance: the evolutionary ecology and genomics of herbicide tolerance. In: STEWART JR, C. N. (Ed.). Weedy and invasive plant genomics. Ames. Iowa: Wiley-Blackwell, 2009.
BELZ, R. G.; HURLE, K. A novel laboratory screening bioassay for crop seedling allelopathy. J. Chem. Ecol., v. 30, n. 1, p. 175-198, 2004.

BOGATEK, R.; GNIAZDOWSKA, A. ROS and phytohormones in plant-plant allelopathic interactions. Plant Signal. Behav., v. 2, n. 4, p. 317-318, 2007.

BONANOMI, G. et al. Phytotoxicity, not nitrogen immobilization, explain plant litter inhibitory effects: evidence from solid-state ${ }^{13} \mathrm{C}$ NMR spectroscopy. New Phytol., v. 191, n. 1, p. 1018-1030, 2011.

BOX, J. D. Investigation of the Folin-Ciocalteu phenol reagent for the determination of polyphenolic substances in natural waters. Water Res., v. 17, n. 5, p. 511-525, 1983.

BRADFORD, M. M. A rapid and sensitive method for the quantification of microgram quantities of protein utilizing the principle of protein-dye binding. Anal. Biochem., v. 72, n. 2, p. 248-254, 1976.

BUTTERLY, C. R. et al. The contribution of crop residues to changes in soil pH under field conditions. Plant Soil., v. 366, n. 1-2, p. 185-198, 2013.

CHEEMA, Z. A.; KHALIQ, A. Use of sorghum allelopathic properties to control weeds in irrigated wheat in a semi arid region of Punjab. Agric. Ecosyst. Environ., v. 79, n. 2-3, p. 105-112, 2000.

DHINDSA, R. S. et al. Leaf senescence: correlated with increased levels of membrane permeability and lipid peroxidation, and decreased levels of superoxide dismutase and catalase. J. Exper. Bot., v. 32, n. 1, p. 93-101, 1981.

EGLEY, G. H.et al. Role of peroxidase in the development of water impermeable seed coats in Sida spinosa L. Planta, v. 157, n. 3, p. 224-232, 1983.

ELLIS, R. A.; ROBERTS, E. H. The quantification of ageing and survival in orthodox seeds. Seed Sci. Technol., v. 9, n. 2, p. 373-409, 1981.

FAROOQ, M. et al. Thermal hardening: a new seed vigor enhancing tool in rice. J. Integr. Plant Biol., v. 47, n. 2, p. 187-193, 2005.

GIANNOPOLITIS, C. N.; RIES, S. K. Superoxide dismuatse: I. occurrence in higher plants. Plant Physiol., v. 59, n. 2, p. 309-314, 1977.

GNIAZDOWSKA, A.; BOGATEK, R. Allelopathic interactions between plants multi-site action of allelochemicals. Acta Physiol. Plant., v. 27, n. 3, p. 395-407, 2005.

HAI-MING, T. et al. Effect of winter cover crops residue returning on soil enzyme activities and soil microbial community in double-cropping rice fields. PLoS ONE., v. 9, n. 6, p. 1-8, 2014. 
HEAP, I. The international survey of herbicide resistant weeds. 2015. (www.weedscience.org).

HUANG, J. H. et al. Allelopathic effects of cassava (Manihot esculenta crantz.) on radish and rye grass (Lolium perene L.). Allelop. J., v. 25, n. 1, p. 155-162, 2010.

IANNUCCI, A. et al. Dynamics of release of allelochemical compounds from roots of wild oat (Avena fatua).

Agrochimica, v. 3, n. 2, p. 21-23, 2012.

INDERJIT, A. M. Soil environment effects on allelochemical activity. Agron. J., v. 93, n. 1, p. 79-84, 2001.

INDERJIT, A. M. Soil microorganisms: an important determinant of allelopathic activity. Plant Soil, v. 274, n. 1-2, p. 227-236, 2005.

INDERJIT, A. M. et al. Determination of allelopathic potential of a weed Pluchea lanceolata through a multifaceted approach. Can. J. Bot., v. 74, n. 9, p. 1445-1450, 1996.

JILANI, G. et al. Allelochemicals: sources, toxicity and microbial transformation in soil - a review. Ann. Microbiol., v. 58, n. 3, p. 351-357, 2008.

KEMMITT, S. J. et al. pH regulation of carbon and nitrogen dynamics in two agricultural soils. Soil Biol. Biochem., v. 38, n. 5, p. 898-911, 2006.

KHALIQ, A.; MATLOOB, A. Germination and growth response of rice and weeds to herbicides under aerobic conditions. Inter. J. Agric. Biol., v. 14, n. 5, p. 775-780, 2012.

KHALIQ, A. et al. Influence of wheat straw and rhizosphere on seed germination, early seedling growth and biochemical attributes of Trianthema portulacastrum. Planta Daninha, v. 29, n. 3, p. 523-533, 2011 b.

KHALIQ, A. et al. Toxic action of aqueous wheat straw extract on horse purslane. Planta Daninha, v. 30, n. 2, p. 269-278, 2012.

KHALIQ, A. et al. Reduced doses of a sulfonylurea herbicide for weed management in wheat fields of Punjab, Pakistan.

Chilean J. Agric. Res., v. 71, n. 3, p. 424-429, 2011 a.

MA, Y. Q. Allelopathic studies of common wheat (Triticum aestivum L.). Weed Biol. Manage., v. 5, n. 3, p. 93-104, 2005.

MARSCHNER, B.; KALBITZ, K. Controls of bioavailability and biodegradability of dissolved organic matter in soils. Geoderma, v. 113, n. 3-4, p. 211-235, 2003.
QASEM, J. R.; FOY, C. L. Weed allelopathy, its ecological impacts and future prospects. J. Crop Prod., v. 4, n. 2, p. 43-119, 2001.

RANDHIR, R.; SHETTY, K. Developmental stimulation of total phenolics and related antioxidant activity in light and dark germinated maize by natural elicitors. Proc. Biochem., v. 40, n. 5, p. 1721-1732, 2005.

RICE, E. L. Allelopathy. 2.ed. London: Academic Press, 1984. p. 309-316.

RIZVI, S. J. H. et al. Weed suppressing ability of bread wheat genotypes under greenhouse and field conditions. In: EUROPEAN ALLELOPATHY SYMPOSIUM-

ALLELOPATHY: FROM UNDERSTANDING TO APPLICATION, 2., Pulawy, Poland: 2004. Proceedings... Pulawy, Poland: 2004. p. 25

RUIYU, L. et al. Impact of allelopathic rice seedlings on rhizospheric microbial populations and their functional diversity. Acta Ecol. Sinica., v. 27, n. 9, p. 3644-3654, 2007.

RYAN, J. et al. Soil and plant analysis laboratory manual. 2.ed. Aleppo, Syria: Jointly published by International Center for Agricultural Research in the Dry Areas (ICARDA) and National Agriculture Research Center (NARC). Avaialable from ICARDA, Aleppo, Syria, 2001.

SAJJAD, M. H. et al. Change in enzyme activity during the decomposition of plant residue in soil. Pak. J. Biol. Sci., v. 5, n. 9, p. 952-955, 2002.

SODAEIZADEH, H. et al. Herbicidal activity of a medicinal plant, Peganum harmala L., and decomposition dynamics of its phytotxins in the soil. Ind. Crop Prod., v. 31, n. 2, p. 385-394, 2010.

STEEL, R. G. D. et al. Principles and procedures of statistics: a biometrical approach. 3.ed. New York: McGraw Hill Book, 1997. p. 172-177.

SUMBELE, S. et al. Photosynthetic capacity is negatively correlated with the concentration of leaf phenolic compounds across a range of different species. AoB. Plants, 2012; 2012: pls025; doi:10. 1093/aobpla/pls025

SWAIN, T.; HILLIS, W. E. The phenolic constituents of Prunus domestica I-the quantitative analysis of phenolic constituents. J. Sci. Food Agric., v. 10, n. 1, p. 63-68, 1995.

SIDDIQUI, I.; BAJWA, R. Variation in weed composition in wheat fields of Lahore and Gujranwala divisions. Pak. J. Biol. Sci., v. 4, n. 1, p. 492-504, 2001.

SIDDIQUI, I. et al. Effect of six problematic weed on growth and yield of wheat. Pak. J. Bot., v. 42, p. 2461-2471, 2010. 
OAD, F. C. et al. Growth and yield losses in wheat due to weed densities. Asian J. Plant Sci., v. 6, n. 1, p. 173-176, 2007.

ELEFTHEROHORINOS, I. G. et al. Metribuzin resistance in Amaranthus retroflexus and Chenopodium album in Greece. Weed Sci., v. 48, n. 1, p. 69-74, 2000.

WESTON, L. A.; DUKE, S. O. Weed and crop allelopathy. Crit. Rev. Plant Sci., v. 22, n. 3-4, p. 367-389, 2003.

WU, H. et al. Laboratory screening for allelopathic potential of wheat (Triticum aestivum) accessions against annual ryegrass (Lolium rigidum). Austr. J. Agric. Res., v. 51, n. 2 , p. 259-266, 2000.
WU, H. et al. Allelopathy in wheat (Triticum aestivum). Ann. Appl. Biol., v. 139, n. 1, p. 1-9, 2001.

ZADOKS, J. C. et al. A decimal code for growth stages of cereals. Weed Res., v. 14, n. 6, p. 415-421, 1974.

ZENG, R. S. et al. Physiological and biochemical mechanism of allelopathy of secalonic acid of higher plants. Agron. J., v. 93, n. 1, p. 72-79, 2001.

ZHANG, E. P. et al. Effect of exogenic benzoic acid and cinnamic acid on the root oxidative damage of tomato seedlings. J. Hortic. For., v. 2, n. 2, p. 22-29, 2010. 